\title{
THE INTER-ORGAN FLUX OF SUBSTRATES IN FED AND FASTED MAN, AS INDICATED BY ARTERIO-VENOUS BALANCE STUDIES
}

\author{
M. ELIA \\ Dunn Clinical Nutrition Centre, 100 Tennis Court Road, Cambridge CB2 1QL
}

CONTENTS

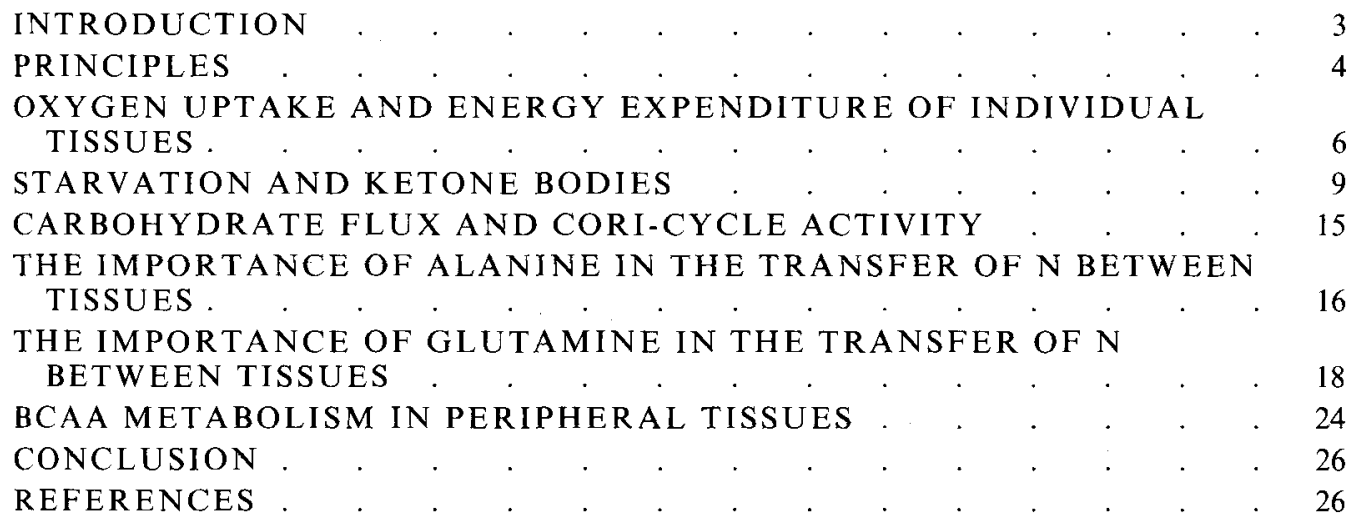

\section{INTRODUCTION}

A $70 \mathrm{~kg}$ man leading a typical Western life-style has a total energy expenditure of about $11 \mathrm{MJ} / \mathrm{d}$, and a basal metabolic rate of about $7 \mathrm{MJ} / \mathrm{d}$. The proportion of energy derived from the oxidation of different fuels is strongly influenced by dietary intake and composition. When the body is in a state of nutrient balance so that its composition does not change, the quantities of fuels ingested are equal to the quantities oxidized and excreted. In affluent societies carbohydrate, fat and protein account for about 45,40 , and $15 \%$ of the energy intake respectively, but in developing countries the proportion of energy derived from carbohydrate may be substantially higher, and that from fat substantially lower (Elia, 1991a).

These gross considerations of metabolism in the whole body give no indication about the contribution of individual tissues to energy expenditure or the types of fuels they use. Furthermore, these considerations give no indication about how metabolism is regulated. The use of arterio-venous (A-V) catheterization studies in humans has demonstrated that the energy expenditure of different tissues can vary 100 -fold, and that the types of fuel used by different tissues also varies substantially. Furthermore, fuel selection by the same tissue can change substantially in the same subject in different circumstances. Catheterization studies have also suggested that the supply of substrates by one tissue may determine metabolic events in another tissue (metabolic control by substrate supply). Therefore, in order to understand the link between dietary intake (or dietary deprivation) and tissue metabolic function, it is necessary to consider metabolic events in individual tissues.

Measurements of the rate of exchange of metabolites across tissues provides one of the few ways in which metabolic processes in individual tissues can be studied in vivo. The 
present review aims to discuss briefly some of the principles involved in estimating the flux of metabolites across tissues, and to highlight the development of some important physiological concepts that have emerged recently from this line of investigation. The review does not aim to deal comprehensively with all aspects of the inter-organ flux of nutrients.

It focuses on energy expenditure of individual tissues and the exchange of ketone bodies, glucose plus glycolytic products, and certain key amino acids in various nutritional and pathophysiological states. It does not focus on the exchange and regulation of nonesterified fatty acids and triacylglycerol across tissues such as adipose tissue.

\section{PRINCIPLES}

Although the measurement of $\mathrm{A}-\mathrm{V}$ concentration differences of metabolites across a tissue gives an indication about whether the tissue takes up or releases metabolites, it gives little indication about the rate of exchange. In order to do this it is obviously necessary to multiply measurements of $\mathrm{A}-\mathrm{V}$ concentration differences of metabolites, with estimates of blood flow (rate of exchange $(\mathrm{nmol} / 1$ tissue per $\mathrm{min})=\mathrm{A}-\mathrm{V}$ concentration difference $(\mu \mathrm{mol} / \mathrm{l}) \times$ blood flow $(\mathrm{ml} / 1$ tissue per $\mathrm{min}))$. This simple procedure involves a number of assumptions which are briefly discussed later so that the limitations of the techniques used to study metabolism in vivo can be appreciated.

1. The most accurate quantitative results are obtained when the circulating concentrations of metabolites are constant or nearly constant, and the measurements are made in whole blood. Since arterial and venous blood samples are normally taken simultaneously, accurate estimations of the rate of exchange of metabolites between blood and tissues are more difficult if the concentration of metabolites on the arterial side of the circulation changes substantially during a period of time equal to the transit time of blood through a tissue. If such changes are ignored the errors can be large, especially when the transit time of blood through a tissue is long and the arterial concentration of metabolites changes rapidly.

It is also preferable to measure the concentration of metabolites in whole blood rather than plasma since erythrocytes play an important role in the inter-organ flux of metabolites (Elwyn et al. 1972; Felig et al. 1973 b).

2. In $\mathrm{A}-\mathrm{V}$ catheterization studies it is frequently assumed that samples of venous blood arise specifically from the tissue under investigation. For example, in studies of forearm metabolism it is assumed that the blood obtained from one of the deep branches of the antecubital vein drains muscle almost exclusively. This may not be the case since the deep venous system has some tributaries from the superficial venous system, which drains skin and adipose tissue. In forearm catheterization studies the customary procedure of inflating a sphygmomanometer cuff placed around the wrist to a pressure above systolic blood pressure, not only has the effect of excluding the hand circulation from the forearm preparation, but also of preventing the wrist perforators from draining blood from the superficial venous system into the deep venous system. Even so, the deep venous system may still receive a contribution of blood from the superficial venous system via a few venous perforators in the forearm.

In $\mathrm{A}-\mathrm{V}$ catheterization studies of subcutaneous abdominal adipose tissue it is assumed that the cannulated abdominal vein receives blood almost exclusively from adipose tissue and not from the skin or underlying muscle. However, some of the blood draining skin probably reaches the cannulated abdominal vein.

In regional catheterization studies of the brain the positioning of the venous catheter in 
the jugular bulb is important for obtaining blood that has a minimum contribution from non-nervous tissue.

3. In studies of regional tissue metabolism it is assumed that blood flow measurements are accurate and specific to the tissue under investigation. A variety of different regional blood flow techniques have been used in such studies. For example, dye-dilution techniques (Wahren et al. 1976) and plethysmography (Aoki et al. 1981; Elia et al. 1988) have been used for measuring limb blood flow, dye-clearance techniques for measuring renal (Owen \& Robinson, 1963) or hepatic blood flow (Wahren et al. 1976), thermodilution techniques for measuring blood flow to the inter-scapular region (Brundin et al. 1987) and lung (Plumley et al. 1990), and xenon-clearance techniques for measuring blood flow to muscle and adipose tissue (Coppack et al. 1990).

These techniques are based on different assumptions which may not be valid in all circumstances. For example, in clearance techniques for estimating hepatic blood flow, it is assumed that there is essentially complete uptake of the marker from the blood perfusing the liver, but this may not be the case, especially when there is liver dysfunction.

Muscle blood flow has often been estimated by limb plethysmography, which measures blood flow to the whole limb and not just muscle. Therefore, it is necessary to make further assumptions about the distribution of blood between muscular and non-muscular limb tissues. A more direct method for measuring blood flow to muscle is nutritive blood flow, which involves measuring the fractional rate of loss of radioactive xenon, which has been directly injected into muscle. However, in calculating blood flow using this technique, assumptions have to be made about the partition coefficient of xenon between muscle and blood. This coefficient provides a measure of the ease with which xenon is 'washed out ' of the tissue by the blood perfusing it. The partition coefficients for muscle and skin are similar to each other, but that for adipose tissue is more than tenfold greater due to the higher 'solubility' of xenon in adipose tissue. It is likely that some differences in the partition coefficient exist for different muscles in the same individual and the same muscle in different individuals. The muscles of obese individuals, which have a greater amount of fat, are expected to have a higher partition coefficient than the muscles of lean individuals, which have a smaller amount of fat.

In recent studies of forearm and calf muscle blood flow, estimates obtained using forearm plethysmography were found to be as much as twofold greater than those obtained simultaneously using the xenon method (A. Kurpad \& M. Elia, unpublished results). Possible explanations for these observations include a high contribution of non-muscular tissues to forearm blood flow, and a particularly low blood flow (or high partition coefficient) to the specific muscle that was injected with xenon, compared with other forearm muscles, which were not injected.

In view of the previously discussed uncertainties it is better to regard the results of some A-V studies as semi-quantitative. Their accuracy depends on the type of tissue investigated and the techniques employed. In studies where regional blood flow measurements are not available, some qualitative conclusions can still be made about fuel selection or the fate of a substrate within a tissue, e.g. the rate of uptake or release of one substrate relative to that of another.

Extrapolation of results obtained from the study of a specific tissue (e.g. muscle or adipose tissue) to the whole mass of the same tissue in the whole body is associated with further uncertainties. This is because further assumptions have to be made about the similarity in metabolic behaviour between the specific tissue investigated and the same type of tissue in other parts of the body. In such calculations it is obviously necessary to estimate the mass of that tissue within the body (Elia \& Jebb, 1990 a,b).

Despite the previously mentioned difficulties and uncertainties, the results of regional 
catheterization studies, with or without concomitant measurements of regional blood flow, have made an enormous impact on concepts of tissue metabolism in health and disease. A few examples will be discussed.

\section{OXYGEN UPTAKE AND ENERGY EXPENDITURE OF INDIVIDUAL TISSUES}

The energy expenditure of the whole body is usually estimated from the amount of $\mathrm{O}_{2}$ used by the body and the amount of carbon dioxide it produces. The energy expenditure of tissues in vivo is normally assessed from the rate of $\mathrm{O}_{2}$ consumption alone. This is partly because estimates of the $\mathrm{O}_{2}$ content of the blood supplying and draining tissues can be made readily and accurately from measurements of the circulating concentration of haemoglobin and the percentage saturation with $\mathrm{O}_{2}$, and partly because the $\mathrm{O}_{2}$ content of arterial blood is substantially higher than in venous blood, e.g. for 'muscle' it is frequently about 30-50\% higher. In contrast, accurate measurements of the $\mathrm{CO}_{2}$ content of whole blood may be more difficult, and the percentage difference between the $\mathrm{CO}_{2}$ content of arterial and venous blood is lower than that for $\mathrm{O}_{2}$. This is because the circulating pool of $\mathrm{CO}_{2}$ is greater than that of $\mathrm{O}_{2}$. Therefore, small errors in measuring the circulating concentration of $\mathrm{CO}_{2}$ in whole blood may produce substantial errors in the estimate of $\mathrm{CO}_{2}$ production by a tissue. However, fortunately, $\mathrm{O}_{2}$ consumption alone is a good indicator of energy expenditure. Table 1 shows that there is only a small variation in the energy equivalents of $\mathrm{O}_{2}$ associated with the oxidation of different fuels. Furthermore, the $\mathrm{O}_{2}$ content of arterial blood remains remarkably constant in most circumstances and, therefore, the estimate of the $\mathrm{O}_{2}$ uptake of a tissue is not subject to some of the non-steady state problems discussed previously.

One of the important contributions of $\mathrm{A}-\mathrm{V}$ studies to energy metabolism is that they have established that the $\mathrm{O}_{2}$ consumption of different tissues varies widely. Table 2 summarizes the results of organ metabolic rates and the estimated distribution of energy expenditure between the tissues of 'reference man' (Snyder et al. 1975). From this it is apparent that the liver, brain, heart and kidney, which account for only about $60 \mathrm{~g} / \mathrm{kg}$ body-weight, are responsible for about $60 \%$ of the energy expenditure of the whole body. The lungs may also make a substantial contribution to the energy expenditure of the body, but adequate values for the $\mathrm{O}_{2}$ consumption of the lungs in vivo are not available due to the difficulties in making an assessment whilst there is a large gaseous exchange with the surrounding atmosphere.

Muscle, which was once thought to make a major contribution to resting energy expenditure because of its large size (about $400 \mathrm{~g} / \mathrm{kg}$ body-weight), probably only accounts for about one-fifth of the total energy expenditure. Although the exact amount is still uncertain, some workers have suggested that the variability in the energy expenditure of resting muscle is a major contributor to the variability in basal metabolic rate (BMR; Zurlo et al. 1990). This conclusion is based on a number of assumptions associated with A-V catheterization techniques and estimation of muscle blood flow (see p. 5) in individuals with different forearm composition. Adipose tissue has an even lower energy expenditure than muscle, although there is little information about regional variations. Nevertheless, extrapolation of measurements made on subcutaneous abdominal adipose tissue (Elia, $1991 b$ ) to the whole mass of adipose tissue within the body, provides estimates that are similar to those calculated by a statistical method which depends on measurements of body composition and energy expenditure (Garby et al. 1987). These estimates also agree closely with those based on the $\mathrm{O}_{2}$ consumption of adipocytes in vitro (Hallgren et al. 1989). However, it should be emphasized that for a variety of other tissues, measurements of $\mathrm{O}_{2}$ 
Table 1. The energy equivalents of oxygen for various substrates (oxidation to carbon dioxide and water)*

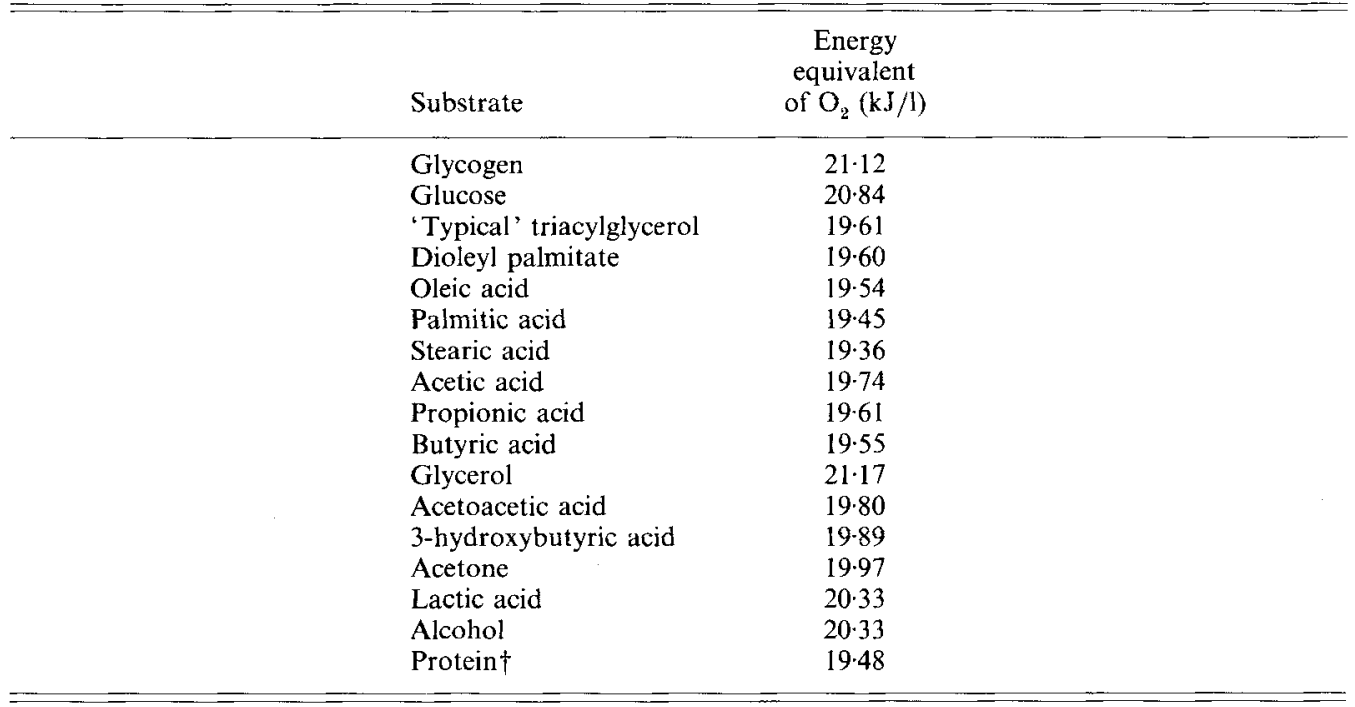

* Based on Livesey \& Elia (1988) and Weast (1976). The heats of combustion of fatty acids were calculated using the formula given by Livesey \& Elia (1988).

$\uparrow$ The value refers to the oxidation of protein in the whole body to urea, ammonia and creatinine in the nitrogenous ratio of $95: 5: 5$. The energy equivalents of $\mathrm{O}_{2}$ for individual amino acids are close to the general value for protein (Livesey \& Elia, 1988).

Table 2. The distribution of weight and the protein content of a $70 \mathrm{~kg}$ man and the estimated contribution of different tissues and organs to basal metabolic rate $(B M R)^{*}$

\begin{tabular}{|c|c|c|c|c|c|c|c|}
\hline & \multicolumn{2}{|c|}{ Wt of tissue } & \multirow[b]{2}{*}{$\begin{array}{l}\text { Protein } \\
\text { content } \\
(\mathrm{kg})\end{array}$} & \multicolumn{4}{|c|}{ Organ/tissue metabolic rate } \\
\hline & $\mathrm{kg}$ & $\%$ body-wt & & $\begin{array}{c}\mathrm{MJ} / \mathrm{kg} \\
\text { per } \mathrm{d}\end{array}$ & $\begin{array}{l}\mathrm{MJ} / \mathrm{kg} \\
\text { protein } \\
\text { per d }\end{array}$ & $\mathrm{MJ} / \mathrm{d}$ & $\begin{array}{c}\% \text { BMR } \\
(7.03 \mathrm{MJ} / \mathrm{d})\end{array}$ \\
\hline Liver & 1.8 & $2 \cdot 6$ & $0 \cdot 32$ & 0.84 & $4-7$ & $1 \cdot 51$ & 21 \\
\hline Brain & $1 \cdot 4$ & $2 \cdot 0$ & $0 \cdot 11$ & $1 \cdot 00$ & $12 \cdot 8$ & $1 \cdot 41$ & 20 \\
\hline Heart & $0 \cdot 33$ & 0.5 & $0 \cdot 055$ & 1.84 & $11 \cdot 0$ & 0.61 & 9 \\
\hline Kidney & $0 \cdot 31$ & $0-4$ & 0.053 & $1 \cdot 84$ & $10 \cdot 8$ & 0.57 & 8 \\
\hline Muscle & $28 \cdot 0$ & 400 & $4 \cdot 80$ & 0.054 & $0 \cdot 32$ & $1 \cdot 52$ & 22 \\
\hline Adipose tissue & 15.0 & $21 \cdot 4$ & 0.75 & 0.019 & 0.37 & 0.28 & 4 \\
\hline $\begin{array}{l}\text { Miscellaneous by } \\
\text { difference (e.g. skin, } \\
\text { intestine, bone, } \\
\text { glands) }\end{array}$ & $23 \cdot 16$ & $33 \cdot 1$ & $4 \cdot 51$ & 0.049 & 0.25 & $1 \cdot 13$ & 16 \\
\hline Whole body & 70 & 100 & $10 \cdot 6$ & $0 \cdot 10$ & 0.66 & 7.03 & 100 \\
\hline
\end{tabular}

* The weight of tissues and their protein content correspond to those of 'reference man' (Snyder et al. 1975). The values for the heart are without blood in its chambers.

consumption in vitro agree poorly with those obtained in vivo by $\mathrm{A}-\mathrm{V}$ catheterization techniques (Davies, 1961). The in vitro results are influenced by the composition of the incubating medium, and the altered electrical activity or tension of tissues such as brain and muscle. Furthermore, even for other tissues such as the lung, the $\mathrm{O}_{2}$ consumption of tissue 
slices may be considerably greater than that of lung perfusion systems (Davies, 1961), which are more physiological.

Fig. 1 shows the distribution of energy expenditure between different organs in a $70 \mathrm{~kg}$ man and a child, 0.5 years, weighing $7.5 \mathrm{~kg}$. In the child the brain alone accounts for about $45 \%$ of energy expenditure, but the value decreases as the child grows older. In contrast, muscle accounts for only about $6 \%$ of energy expenditure in the $7.5 \mathrm{~kg}$ child, but this increases to about $20 \%$ in the 'reference' adult male. This is partly due to the smaller proportion of muscle in the young infant (about $250 \mathrm{~g} / \mathrm{kg}$ body-weight compared with about $400-450 \mathrm{~g} / \mathrm{kg}$ body-weight in the adult), and a greater proportion of organs, which are metabolically more active (about $100 \mathrm{~g} / \mathrm{kg}$ body-weight for the sum of liver, kidneys, brain, and heart, compared with $60 \mathrm{~g} / \mathrm{kg}$ body-weight in the adult).

Despite limited information (Elia, 1991b) there appears to be little change in the rate of $\mathrm{O}_{2}$ consumption per unit weight of organs or tissue in individuals of different age and sex. Although there is a twofold difference in whole-body BMR $/ \mathrm{kg}$ body-weight between a 6month-old child and an adult, the values for BMR/ $\mathrm{kg}$ organ weights (sum of liver, kidney, heart and brain) remain remarkably constant during growth and development (Elia, $1991 \mathrm{~b}$ ). Therefore, the twofold difference in BMR between infancy and adulthood can be largely explained by differences in the proportion of metabolically active tissues (mainly organs) relative to less-active tissues (mainly adipose tissue and muscle).

These observations raise important points about the mechanisms of energy adaptation in starvation and malnutrition. It is possible to conserve energy by either reducing the proportion of metabolically active tissues relative to less-active tissues, or by reducing the metabolic rate/unit weight of individual tissues. Unfortunately there have been few studies undertaken to distinguish between these possibilities, although both seem likely. Animal studies involving dietary manipulation suggest that major changes in organ size may occur with little change in organ metabolic rate $\left(\mathrm{O}_{2}\right.$ consumption $/ \mathrm{kg}$ organ weight; Burrin et al. 1989). Furthermore, studies in rats suggest that the intra-abdominal organs may be lost at a greater rate than skeletal muscle during starvation (Addis et al. 1936).

Changes in the relative proportions of tissues have also been documented in experimental studies of injury and sepsis. In some of these, an increase in the size of the liver has been noted, despite weight loss, muscle wasting and a negative nitrogen balance (Wusteman \& Elia, 1990). These observations suggest that there has been net transfer of $\mathrm{N}$ from muscle to liver. Therefore, the increase in metabolic rate that commonly occurs in sepsis/injury could at least be partly due to the presence of more tissues such as liver, relative to muscle. Such considerations probably also apply to humans since the size of intra-abdominal organs relative to muscle appears to remain higher in patients with malignancy than those with anorexia nervosa (Heymsfield \& McManus, 1985).

Regional catheterization studies in hypermetabolic patients, e.g. those suffering from severe burns, have shown that $\mathrm{O}_{2}$ consumption is increased in a variety of different tissues (Wilmore \& Aulick, 1978). Although this increase may be partly due to an increase in the size of some organs, a more important mechanism probably involves a rise in the metabolic $\mathrm{rate} / \mathrm{kg}$ individual tissues. In patients with severe burns whole-body metabolic rate may increase by more than $50 \%$ above normal (Elia, 1990). If this was entirely due to an increase in the size of organs, their size would have to double. Since this does not occur it is likely that there is an increase in the metabolic rate $/ \mathrm{kg}$ organ. Acute elevations in the rate of $\mathrm{O}_{2}$ consumption in individual human tissues resulting from the administration of stress hormones (glucagon, catecholamines and cortisol), are almost certainly due to an increase in the metabolic rate $/ \mathrm{kg}$ individual tissues. There is clearly insufficient time for any redistribution of protein to occur within the body.

One of the important thermogenic tissues in small animals is brown fat. This tissue is also 


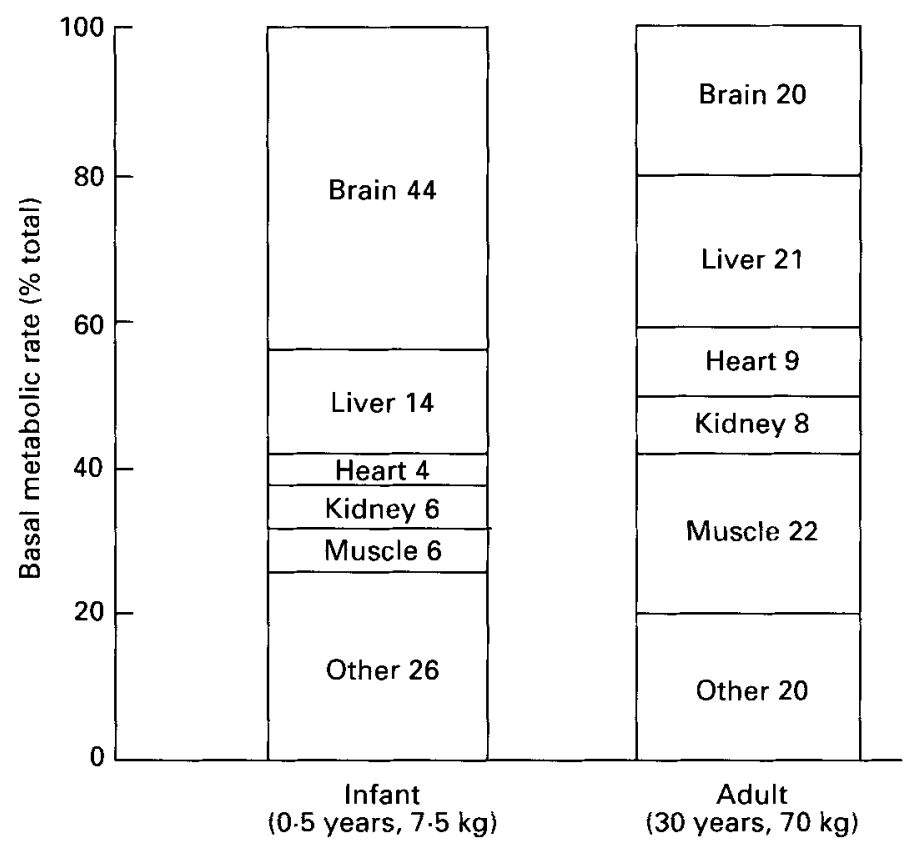

Fig. 1. The estimated distribution of energy expenditure in an infant $(0.5$ years, $7.5 \mathrm{~kg})$ with a basal metabolic rate of $1.63 \mathrm{MJ}(390 \mathrm{kcal}) \mathrm{d}$, and an adult (30 years, $70 \mathrm{~kg}$ ) with a basal metabolic rate of $7.03 \mathrm{MJ}(1680 \mathrm{kcal}) \mathrm{d}$.

present in human infants and adults, particularly in the peri-renal and inter-scapular regions. However, there has been controversy about the contribution of brown fat to energy expenditure, particularly in adult man. A recent $\mathrm{A}-\mathrm{V}$ study in adults aged $20-36$ years (Brundin et al. 1987) attempted to examine the importance of the inter-scapular brown fat depot in energy production, by measuring the heat released and the $\mathrm{O}_{2}$ consumption of the tissues draining into the azygos vein. This vein drains a large skin area including that in the thoracic wall, and the inter-scapular brown adipose tissue. The average azygos vein blood flow was found to be $94 \mathrm{ml} / \mathrm{min}$ and the $\mathrm{O}_{2}$ consumption, $6 \mathrm{ml} / \mathrm{min}$, which is equivalent to about $2.5 \%$ of the measured whole-body $\mathrm{O}_{2}$ consumption. Using a thermodilution technique it was also estimated that the heat flow from the tissues drained by the azygos vein was only about $0.5 \mathrm{~W}$. This study suggests that the quantitative importance of this area to energy expenditure is small, at least in the resting and fasted state. It does not support the concept that the inter-scapular brown fat depot contributes significantly to energy expenditure under the circumstances of the study, although it is possible that brown fat activity may increase considerably after 'stress'. However, the major increase in the $\mathrm{O}_{2}$ consumption of the splanchnic area, which has been noted after injury and infusion of 'stress' hormones in humans (catecholamines, glucagon, and cortisol either alone or in combination) is unlikely to be due to increased brown fat activity in the liver because this tissue has little or no brown fat (or the 32000 dalton mitochondrial uncoupling protein which is responsible for the thermogenic activity of brown adipose tissue).

\section{STARVATION AND KETONE BODIES}

Regional catheterization studies have shown that after an overnight fast the liver releases glucose at a rate of about $200 \mathrm{~g} / \mathrm{d}$, and that the brain utilizes more than half this (about 
$120 \mathrm{~g} / \mathrm{d})$. During starvation, when glycogen stores are depleted, glucose is formed predominantly from amino acids (about 100 amino acids form $65 \mathrm{~g}$ glucose) and the glycerol moiety of triacylglycerol. If during starvation the brain continued to depend on glucose as its main energy source, lean tissues would have to break down rapidly to provide the amino acids necessary for gluconeogenesis. The lean tissues would quickly become depleted and this would reduce survival time. Fatty acids are not important fuels for the brain during starvation, partly because they do not readily pass through the blood-brain barrier, and partly because the enzymes involved in their oxidation are lacking from the brain.

The quantitative importance of ketone bodies as a fuel for the brain during starvation was recognized by Owen et al. (1967), who studied brain metabolism by A-V catheterization techniques in obese individuals undergoing therapeutic starvation. Ketone bodies, which are water soluble and readily cross the blood-brain barrier, were found to become the most important fuel for the brain during prolonged starvation. This has the advantage of sparing glucose and, therefore, reducing the need to catabolize lean tissues, which provide amino acids for gluconeogenesis. The main reason why ketone bodies become the major energy substrate for the brain during starvation (Robinson \& Williamson, 1980) is that their availability increases dramatically (i.e. a mass action effect). The blood concentration of acetoacetate $(\mathrm{AcAc})$ plus 3-hydroxybutyrate $(\mathrm{BOH})$ rises from a normal post-absorptive value of about $0 \cdot 1 \mathrm{mmol} / 1$ to more than $5 \mathrm{mmol} / \mathrm{l}$ during prolonged starvation. No other energy substrates show such an increase during starvation. Indeed, the circulating concentration of glucose, which is normally the major substrate for brain metabolism, falls during starvation. The large variability in circulating ketone-body concentration in different pathophysiological states not only allows these metabolites to become important energy substrate in tissues distant from their hepatic site of production, but also important signals for metabolic regulation (Robinson \& Williamson, 1980), e.g. they inhibit the utilization and oxidation of glucose.

During starvation ketone bodies were also found to become important fuels for other tissues such as muscle and heart. The forearm catheterization studies of Owen \& Reichard (1971) showed that during early starvation ( $3 \mathrm{~d}$ ) in obese individuals about $50 \%$ of the $\mathrm{O}_{2}$ consumption of muscle could be accounted for by the uptake of ketone bodies ( $\mathrm{BOH}$ and AcAc). However, the situation was found to change during prolonged starvation (3 weeks). AcAc continued to be taken up by muscle at a high rate, but some of it appeared to be converted to $\mathrm{BOH}$, which was released. As a consequence only about $18 \%$ of the $\mathrm{O}_{2}$ uptake could be accounted for by the net oxidation of ketone bodies. Other studies suggested an even lower contribution of ketone bodies to the oxidative metabolism of forearm muscle during prolonged starvation (about $10 \%$ by Hagenfeldt \& Wahren, 1971). The effect of these changes is to reduce the high rate of ketone-body utilization, which occurs in peripheral tissue during early starvation, and replace them with non-esterified fatty acids (NEFA). The ketone bodies, which are spared from peripheral tissue metabolism, increase in concentration and become available for the brain, which does not utilize NEFA directly.

The reduced rate of utilization of ketone bodies by forearm muscle during prolonged starvation (compared with early starvation; Owen \& Reichard, 1971) raises questions about the mechanisms responsible for the change. It is not due to a reduction in the availability of ketone bodies because their circulating concentration doubled between $3 \mathrm{~d}$ and 3 weeks of starvation. However, it is possible that the activity of the enzymes involved in ketone-body metabolism in muscle decreases as starvation progresses.

The 'classic' changes in fuel selection described previously for obese individuals do not necessarily apply to all subjects. Little attention has been given to possible metabolic differences that may exist between lean and obese individuals. Indeed, measurement of the 


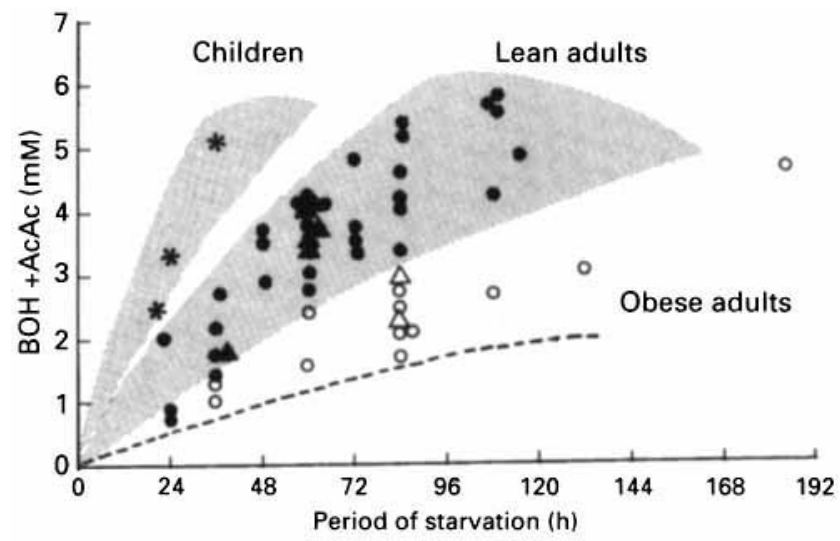

Fig. 2. Comparison of D-3-hydroxybutyrate $(\mathrm{BOH})$ plus acetoacetate (AcAc) concentrations in whole blood in lean $(\boldsymbol{O}, \boldsymbol{A})$ and obese adults $(O, \triangle)$, and 5-7-year-old children $(\star)$ during starvation. $(\boldsymbol{O}$, $0)$, Venous concentration; $(\boldsymbol{\Lambda}, \triangle)$, arterial or (arterialized) blood concentration. The graph was compiled from the results obtained by the following authors: Owen et al. 1969; Owen \& Reichard, 1971, 1975; Owen et al. 1973; Reichard et al. 1974, 1979; Sapir \& Owen, 1975; Merimee et al. 1978; Elia et al. 1980, 1984a, b; Morrow et al. 1981; Haymond et al. 1982; Bjorkman \& Eriksson, 1983, 1985; Swaminathan et al. 1982; Jensen et al. 1987; Eriksson et al. 1988; Elia, unpublished results. Each point represents a mean value of at least four measurements of ketone bodies which were measured enzymically as $\mathrm{AcAc}+\mathrm{BOH}$. In studies where plasma or serum concentrations were measured the results were multiplied by 0.84 to obtain the estimated concentration in whole blood. Only studies with welldefined periods of starvation and no energy intake were included. Studies of lean individuals with a body mass index $>25 \mathrm{~kg} / \mathrm{m}^{2}$ were excluded. In some cases results were obtained from graphs (Merimee $e t$ al. 1978; Morrow et al. 1981; Haymond et al. 1982; Owen \& Reichard, 1975), whilst others were calculated from individual data (Reichard et al. 1974). Only data of post-menopausal women were included from Morrow et al. (1981) because the other women were receiving sex hormones. Studies which did not meet the previously stated criteria were excluded (Felig et al. 1971; Balasse \& Neef, 1975; Foster et al. 1979; Garber et al. 1974; Cahill et al. 1966; Goschke 1977; Goschke et al. 1977; Owen et al. 1981; Fery \& Balasse, 1983, 1986; Balasse 1979; Bougneres \& Ferre 1987).

circulating ketone-body concentration in different groups of subjects (children, and lean and obese adults) suggests that there may be importance differences between them. The rate at which blood ketone-body concentrations (and $\mathrm{BOH}: \mathrm{AcAc}$ ratio) rise during early starvation may be twice as fast in lean adults than in obese adults. The rate of rise in children is even greater. Such changes are illustrated in Figs 2 and 3, which were constructed from the results of a large number of studies according to the criteria indicated.

It has also been reported that the ketone-body concentration rises more rapidly in females than in males (Goschke et al. 1976; Haymond et al. 1982), and, in prolonged starvation the rise may be greater in older individuals than younger subjects (Hall et al. 1984). These observations do not explain the differences in ketone-body concentration between the lean and obese subjects indicated in Fig. 2, because a greater proportion of the obese subjects were older and female compared with the lean subjects.

Table 3 summarizes the results of ketone-body production rates estimated by $\mathrm{A}-\mathrm{V}$ catheterization and tracer techniques in lean and obese individuals undergoing short-term starvation. The obese subjects maintain a lower circulating ketone-body concentration despite a similar or even a possibly higher rate of ketone-body production than the lean. Since muscle is an important site of ketone-body utilization in the obese, this prompted our group (Elia et al. 1990) to undertake forearm catheterization studies in lean male individuals after an overnight fast (12-14 h of starvation), and between $36-40$ and $60-66 \mathrm{~h}$ of starvation. These studies during early starvation showed that muscle took a substantial amount of AcAc and released $\mathrm{BOH}$, a phenomenon that was observed in obese individuals 


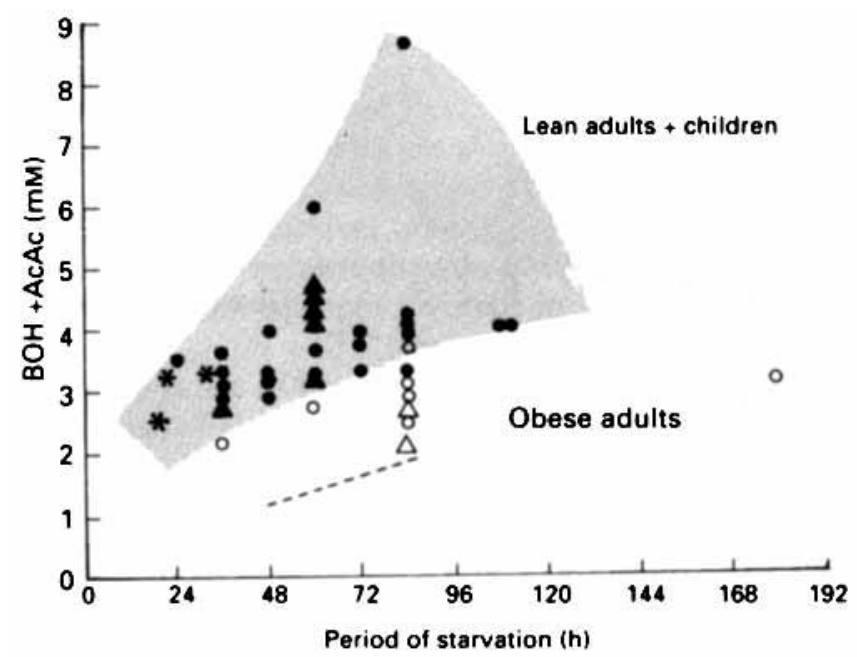

Fig. 3. Comparison of the circulating molar ratio, D- $\beta$-hydroxybutyrate $(\mathrm{BOH})$ :acetoacetate (AcAc) in lean $(\boldsymbol{O}, \boldsymbol{\Delta})$ and obese adults $(O, \triangle)$, and 5-7-year-old children $(\star)$ during starvation. $(O, O)$, Venous blood, $(\mathbf{\Lambda}, \triangle)$, arterial blood. The graph was constructed using the same references and selection criteria as in Fig. 2.

only during prolonged starvation. This release of $\mathrm{BOH}$ can help explain why the circulating concentration of $\mathrm{BOH}$ rises much more rapidly in lean individuals than in the obese. The contribution of ketone bodies to oxidative metabolism in lean subjects was estimated to be about $5 \%$ after an overnight fast, $10 \%$ after $36-40 \mathrm{~h}$ of starvation, and $20 \%$ after $60-66 \mathrm{~h}$ of starvation. In this study of short-term starvation (Elia et al. 1990), the dominant energy source for forearm metabolism was found to be fatty acids (cf. obese individuals (Owen \& Reichard, 1971)). The reason for the apparent differences in ketone body and fatty acid metabolism between lean and obese subjects during early starvation is uncertain, but the lean subjects investigated by Elia et al. (1990), were healthy young male adults, whilst the obese subjects studied by Owen \& Reichard (1971) were older, predominantly female, and had conditions other than obesity (diabetes, heart failure, polycythaemia). Although sex, age and obesity may affect muscle size and composition, and alter both the circulating insulin concentration and insulin sensitivity in muscle, the extent to which these factors contribute to the previously described metabolic differences is uncertain.

There has also been an interest in the relationship between ketogenesis and $\mathrm{N}$ conservation during starvation. Since ketone bodies replace glucose as an oxidative fuel (Fig. 4), this reduces the need for gluconeogenesis from net protein breakdown. However, some workers have pointed out that the fractional contribution of protein oxidation to energy expenditure (BMR) may not decrease during starvation (Henry et al. 1986). Elia \& Parkinson (1989) agreed that this may be the case in lean individuals, but pointed out the remarkable protein economy that occurs in obese individuals undergoing prolonged starvation. It has been known since the beginning of the century, and possibly earlier, that survival during starvation in a variety of species depends on the size of the energy stores, which differ to a much greater extent between lean and obese individuals than the available 'protein stores'. Teleologically, the reduced contribution of protein oxidation to total energy expenditure in obese individuals undergoing prolonged starvation seems to be important for survival since it allows a degree of 'parallel' depletion of the available energy and 'protein' stores. In lean individuals, who are likely to survive for shorter periods of time during starvation than obese individuals, the need to restrict protein loss is less. 


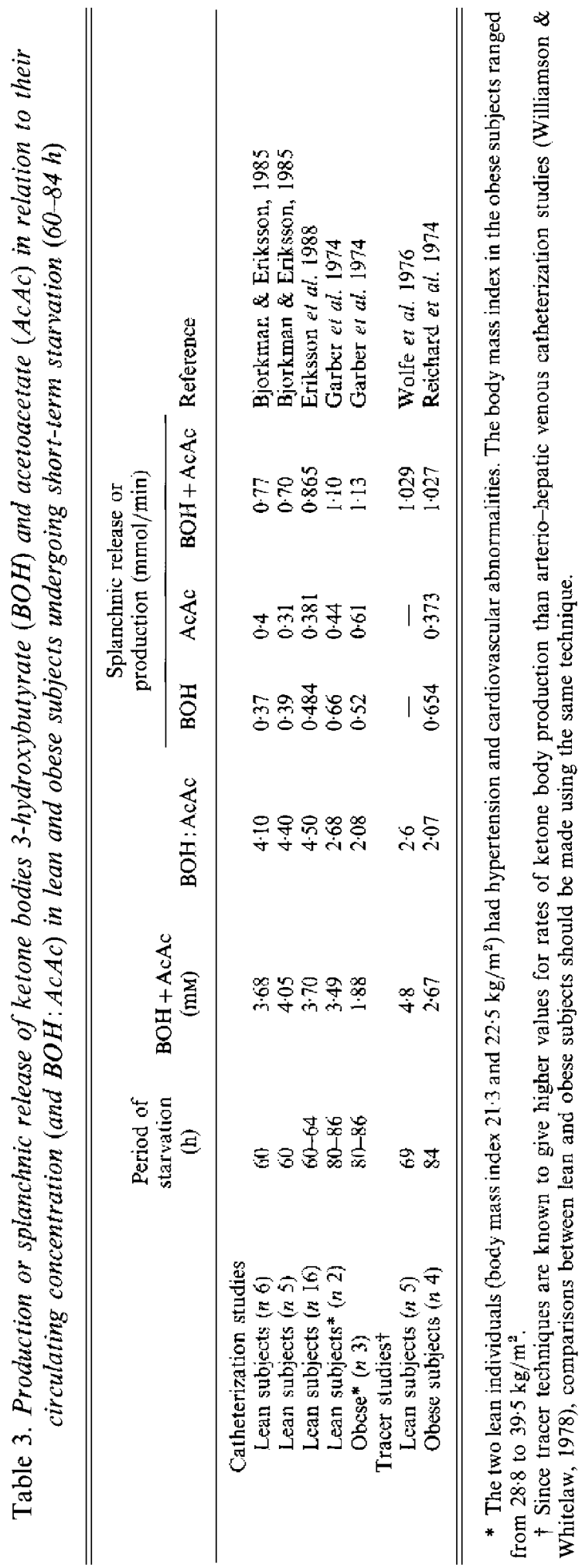




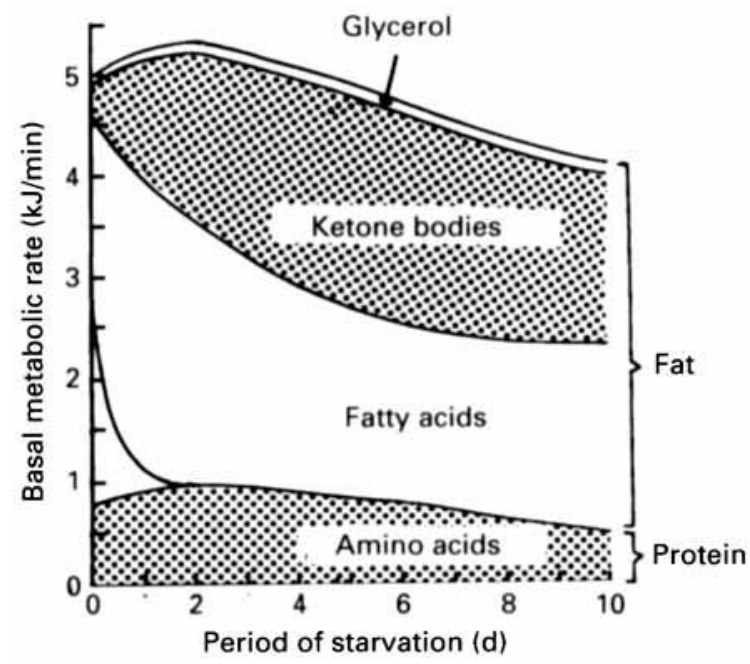

Fig. 4. The likely changes in basal metabolic rate and fuel selection in a lean subject undergoing starvation. Note the transient increase in nitrogen excretion and basal metabolic rate during early starvation. Ketone bodies which are derived from fatty acids become major fuels for the tissues of the body and account for up to about $40 \%$ of basal energy expenditure.

The signals that act as a link between adipose tissue mass and the rate of protein oxidation during prolonged starvation are not entirely understood. Ketone bodies have been implicated since infusions of $\mathrm{BOH}$ reduce net protein breakdown, but the effects are only small. Furthermore, although net glycogen breakdown is considered to have essentially ceased after the first $1 \cdot 5-2 \cdot 0 \mathrm{~d}$ of starvation, amino acid oxidation judged from urine $\mathrm{N}$ excretion frequently shows a temporary increase $2-4 \mathrm{~d}$ after the onset of starvation (Fig. 4). This occurs despite a progressive increase in ketone-body utilization by various tissues of the body including the brain, which at this time derives more than about one-third of its energy from the oxidation of ketone bodies (Dietze et al. 1980). It is also interesting that the fractional contribution of protein oxidation to energy expenditure during the first $6 \mathrm{~d}$ of starvation is similar or slightly higher in lean subjects than in obese subjects (Goschke et al. 1975), despite the generally higher circulating ketone-body concentrations in lean subjects. Although differences in ketone-body metabolism between lean and obese subjects undergoing prolonged starvation have been poorly documented, it is clear that there are still some uncertainties about the factors that regulate protein catabolism during starvation.

Fig. 4 shows that the changes in fuel selection associated with early starvation are not only associated with a transient increase in $\mathrm{N}$ excretion but also a transient increase in BMR (for a summary of the changes in BMR, see Pullicino \& Elia, 1991). A variety of factors probably contribute to this increase in energy expenditure including the following: the energy cost associated with an increase in gluconeogenesis from amino acids; the use of more fat as an energy source which is associated with the release of less heat per mol ATP gained than the oxidation of glycogen (Elia \& Livesey, 1988); the energy cost associated with an increase in triacylglycerol-fatty acid recycling (Elia et al. 1984b) and acetyl coA-ketone body recycling. 


\section{CARBOHYDRATE FLUX AND CORI-CYCLE ACTIVITY}

Not all the glucose-carbon taken up by muscle is oxidized or stored in muscle. Some of it may be released in the form of lactic acid (a product of glycolysis), which is subsequently taken up by the liver to re-form glucose. This glucose may then recirculate back to muscle to complete the so called Cori cycle. Evidence for the existence of this cycle was obtained in vivo from $\mathrm{A}-\mathrm{V}$ catheterization studies of muscle and of the splanchnic bed.

The concept of the Cori cycle was strengthened by repeated observations that muscle preparations increased the release of lactate (and other glycolytic products) when the availability of glucose in the incubating medium was increased. Many considered that this was also the case in vivo. However, forearm catheterization studies showed that intravenous administration of glucose resulted in a several-fold increase in the rate of uptake of glucose by muscle, which was not associated with an increase in the release of lactate or other glycolytic products. Indeed, the release of these products in vivo under the conditions of study tended to decrease. It is likely that most of the glucose taken up by muscle was stored in muscle or oxidized to $\mathrm{CO}_{2}$ and water, leaving little to be released as $\mathrm{C}_{3}$ glycolytic fragments. The increase in circulating insulin concentration not only favours glycogen deposition but also the activation of the pyruvate dehydrogenase complex $(E C$ $1.2 .4 .1,1.8 .1 .4,2.3 .1 .12,3.1 .3 .43)$ which catalyses an important rate-limiting step in the oxidation of glucose (Randle, 1978). The reduced circulating concentration of NEFA, which follows glucose administration, also favours activation of the pyruvate dehydrogenase complex.

The observation that intravenous (Dietze, 1983; Elia et al. 1985) or oral glucose (Jackson et al. 1987) may reduce rather than increase the release of lactate by human muscle, differs from what might be predicted from in vitro studies and by the Cori cycle. Furthermore, other catheterization studies in humans have shown that large doses of oral or intravenous glucose may cause splanchnic tissues to revert from taking up lactate to releasing it (Felig et al. 1975; Felig \& Wahren, 1975; Ferrannini et al. 1980). Therefore, biochemical concepts have to be modified to take into account the new observations.

Although in starvation the availability of carbohydrate is reduced and its uptake by a variety of tissues including muscle is decreased, the release of glycolytic products may be unchanged or even increased (Elia et al. 1990). Certainly the release of lactate relative to the uptake of glucose by muscle is increased (Owen \& Reichard, 1971; Dietze et al. 1978, 1980; Elia et al. 1990). This can be regarded as a consequence of adaptive changes which are associated with preservation of glucose-C. The first irreversible step in the oxidation of glucose is catalysed by the pyruvate dehydrogenase complex which oxidatively decarboxylates pyruvate (pyruvate is also linked to alanine and lactate by near equilibrium reactions). The inhibition of the pyruvate dehydrogenase complex during starvation by the reduced circulating insulin concentration and high concentration of NEFA and ketone bodies, will tend to favour release of glycolytic products.

Another important observation that has emerged from the use of regional catheterization techniques is the high rate of inter-organ flux of lactate in patients with burns (Wilmore \& Aulick, 1978). In severely burned subjects, the wound may utilize the majority of the glucose produced by the liver. However, the burn wound appears to be incapable of oxidizing the glucose that it takes up. Virtually all the glucose- $\mathrm{C}$ is released in the form of lactate. The basis of the glycolytic nature of the burn tissue is uncertain, but it has been suggested that lactate (or a change in local $\mathrm{pH}$ induced by high lactate concentrations) may have a beneficial effect by inhibiting bacterial growth and possibly stimulating fibroblastic activity (Wilmore \& Aulick, 1978). Such studies also show that the damaged peripheral tissues are not the major sites of $\mathrm{O}_{2}$ consumption. Instead, the damage caused by the burn 
initiates a series of neuro-hormonal changes that result in increased metabolic activity in a variety of tissues distant from the site of injury.

\section{THE IMPORTANCE OF ALANINE IN THE TRANSFER OF N BETWEEN TISSUES}

Another important cycle that was clarified as a result of regional catheterization studies of muscle and the splanchnic bed, is the glucose-alanine cycle. The origins of this cycle go back to work in vitro which showed that the perfused liver takes up alanine, and muscle preparations released alanine in preference to other amino acids. In muscle the $\mathrm{N}$ of alanine was derived from other amino acids and its $C$ skeleton from glucose. Essentially, some amino acids transaminated with pyruvate, which is derived predominantly from glucose (although some may be formed from amino acids) to form alanine (Mallette et al. 1969). When the availability of glucose in muscle preparations was increased, the rate of glycolysis was also found to increase (Odessey et al. 1974; Fulks et al. 1975; Snell \& Duff, 1977). This made more pyruvate available for transamination with the result more alanine was formed and released (in conjunction with other glycolytic products (lactate and pyruvate)).

Shortly after the postulation of the giucose-alanine cycle, several $\mathrm{A}-\mathrm{V}$ catheterization studies confirmed that alanine was a major amino acid released by muscle, accounting for about $30 \%$ of the total amino acid released after an overnight fast (c.g. Pozefsky et al. 1969: Felig et al. 1970; Felig, 1973; an important amino acid that was not measured in some of these early studies was glutamine, see pp. 18-24). The predominance of alanine release was not due to the presence of a particularly high alanine content in muscle protein (alanine accounts for about $6 \%$ amino acid residues in muscle protein; Kominz et al. 1954). It was also not due to temporary depletion of the free alanine pool in muscle, since alanine release dominated other amino acids even during prolonged starvation. These observations suggested that alanine was formed in muscle de novo, as was observed in the muscle preparations.

The link between pyruvate and alanine was emphasized by two further sets of observations:

1. Infusion of pyruvate in the human brachial artery resulted in increased alanine release by forearm muscle (Pozefsky \& Tancredi, 1972). In contrast, in a patient with McArdle's syndrome (myophosphorylase deficiency), the normal increase in alanine release that occurs during exercise, did not occur because of the inability to produce increased amounts of pyruvate from glycogen breakdown (Wahren et al. 1973).

2. A positive relationship between circulating alanine and pyruvate concentrations is observed in a variety of situations: basal post-absorptive state (no other amino acid appears to share this relationship with pyruvate); chronic hyperpyruvicaemia associated with inborn errors of metabolism (Lonsdale et al. 1969); exercise (Felig \& Wahren, 1971); Cushings disease and after administration of corticosteroids (Wise et al. 1973); lactic acidosis (Marliss et al. 1971).

The major fate of alanine released by muscle was identified when the flux of alanine was measured across the liver and splanchnic tissues (see Felig, 1973). Between 35 and $50 \%$ of the total amino acid uptake was in the form of alanine. These observations together with those observed in vitro formed the basis of the glucose-alanine cycle. The A-V studies suggested that molar release of alanine exceeded that of pyruvate, although it was not as high as that of lactate. The alanine that was formed in muscle was taken up by the liver, where its $\mathrm{C}$ skeleton was converted to glucose, and its $\mathrm{N}$ was presumably used to form urea. The transfer of $\mathrm{N}$ from muscle to liver is essentially a catabolic process since it involves the 
formation of urea which is the major nitrogenous end-product of protein metabolism. One of the roles of the glucose-alanine cycle is that it transfers $\mathbf{N}$ from the periphery to the liver without the liberation of ammonia which is toxic.

Subsequently, it was found that infusion of alanine or other gluconeogenic substrates into the systemic circulation resulted in increased hepatic uptake of the same substrate. Furthermore, conditions associated with increased release of alanine into the circulation were associated with increased hepatic uptake of alanine by the splanchnic tissues (Aulick \& Wilmore, 1979; Wilmore et al. 1980), whilst conditions associated with decreased peripheral alanine release (e.g. starvation) were associated with decreased splanchnic uptake of alanine (Felig et al. 1969; Felig, 1973). These observations were consistent with the idea that metabolic events in the liver could be controlled by the supply of metabolites such as alanine derived from other tissues (cf. p. 10 for the influence of hepatic ketogenesis on brain metabolism). The observations also suggested that factors that affected the production and release of alanine and other amino acids from peripheral tissues could play an important role in protein economy. It is also possible that independent intrahepatic regulation of metabolism could influencc metabolic events in other tissues by altering the circulating concentration of metabolites such as glucose, lactate, alanine and ketone bodies. The possible interaction between tissues increases when metabolic pathways or cycles start in one tissue but subsequently involve two or more tissues.

Two further observations followed that altered concepts about the importance of alanine in metabolism. The first was the importance of alanine release by muscle in the fed state, and the second was the recognition that glutamine played an even more important role than alanine in the inter-organ flux of $\mathrm{N}$ (see pp. 18-24).

After a protein meal the release of alanine relative to glutamine decreased (Elia \& Livesey, 1983). This was also found to be the case after administration of a mixture of amino acids (Abumrad et al. 1982; Gelfand et al. 1986). Interestingly, after the oral protein meal there was an apparent temporary 'uptake' of alanine, which was followed by $\mathrm{A} \cdot \mathrm{V}$ concentration differences of alanine that remained close to zero despite a nearly constant arterial concentration. In other studies, one of the branched-chain amino acids (BCAA; leucine) was administered alone either orally (Aoki et al. 1981) or intravenously (Elia \& Livesey, 1981, 1983). Since BCAA are metabolized in muscle it was felt that measuring the rate of release of different amino acids from muscle might give a clue as to the fate of the $\mathrm{N}$ present in the BCAA (although possible changes in the pool size of individual amino acids were confounding variables). The results indicated that leucine stimulated glutamine rather than alanine release by muscle (Aoki et al. 1981; Elia \& Livesey, 1981, 1983).

It was then felt that perhaps in situations where glucose availability was increased. the release of alanine may be specifically increased, especially since the availability of pyruvate is also increased in these circumstances. However, administration of oral or intravenous glucose did not increase pyruvate, lactate, or alanine release by muscle (Elia et al. 1985). Indeed their release tended to decrease even when their arterial concentrations were stable. Interestingly, other studies involving administration of large doses of oral or intravenous glucose, suppressed net alanine uptake by splanchnic tissues by as much as $75 \%$ (Felig $e t$ al. 1975; Felig \& Wahren, 1975; Ferrannini et al. 1980). These observations provide further examples of important metabolic processes in vivo that differ from some of those that may be expected from in vitro observations. If glucose administration stimulated alanine release by muscle and subsequent uptake by muscle, as implied by the glucose-alanine cycle, it would result in increased urea formation. Since glucose is protein sparing, the glucose-alanine cycle required re-evaluation (see Elia et al. 1985); however, it should be remembered that other amino acids are involved in the formation of urca in the liver. At the same time the in vivo studies had to explain the mechanism by which the circulating 
alanine concentration was often increased after glucose administration. This may have resulted from reduced uptake of alanine by the splanchnic tissues, as indicated previously (decreased gluconeogenesis from alanine implies decreased urea formation from this source), or increased release of alanine by non-muscular tissues, or a combination of both.

Although the previously described studies emphasize the importance of in vivo studies, they do not necessarily give an indication of the normal metabolic changes induced by nutrients ingested in everyday life. This is because subjects do not normally ingest glucose alone, or leucine alone or even a protein meal that lacks carbohydrate and fat. The effect of a mixed meal on muscle metabolism was first studied by Elia et al. $(1988,1989)$, and subsequently by Coppack et al. 1990 and Frayn et al. 1991. Here again, the release of alanine and other glycolytic products was not increased after a mixed meal despite a major increase in the uptake of glucose (Elia et al. 1989; Frayn et al. 1991). Glutamine carried more $N$ out of muscle than any other amino acid (Elia et al. 1989).

\section{THE IMPORTANCE OF GLUTAMINE IN THE TRANSFER OF N BETWEEN TISSUES}

Perhaps the most important amino acid involved in the inter-organ transfer of amino acids is glutamine. After an overnight fast peripheral tissues release alanine and glutamine in approximately equimolar quantities, but since glutamine contains two $\mathbf{N}$ atoms per molecule, compared with alanine which contains only one atom per molecule, glutamine is twice as important as alanine in carrying $\mathbf{N}$ out of peripheral tissues. Furthermore, after administration of nutrients, e.g. glucose (Elia et al. 1985), BCAA (Aoki et al. 1981; Elia \& Livesey, 1983), protein meal (Elia \& Livesey, 1983; Wahren et al. 1976), and a mixed meal (Elia et al. 1989), glutamine release exceeds that of alanine. Glutamine is now known to be released by a variety of tissues such as muscle, adipose tissue (Frayn et al. 1991), skin plus subcutaneous adipose tissue (K. Khan \& M. Elia, unpublished results) and possibly lung (humans, Plumley et al. 1990; animals, Souba et al. $1990 \mathrm{~b}$ ). It is also taken up by a variety of tissues, notably the gut and kidney, both of which release alanine and other amino acids. A variety of factors influence the exchange of glutamine between blood and various tissues, but in muscle a specific sodium-dependent glutamine transporter has been identified which has been implicated in the fine regulation of glutamine efflux from this tissue (Rennie $e t$ al. 1986).

The early $\mathrm{A}-\mathrm{V}$ studies across muscle and splanchnic tissues failed to identify a specific role for glutamine for at least two reasons. The first was its instability, which is affected by a variety of factors. During storage glutamine may degrade to pyroglutamic acid or glutamic acid to an extent which depends on temperature, $\mathrm{pH}$, and the concentration of other substances (Khan \& Elia, 1991) or enzymes stored with glutamine. The rate of degradation of glutamine to glutamic acid in plasma is strongly influenced by the activity of $\gamma$-glutamyl transferase (EC 2.3.2.2; da Fonseca-Wollheim, 1990), which can be increased more than twentyfold in patients with liver dysfunction. The second reason was that glutamine was frequently not separated chromatographically from other amino acids such as asparagine and glutamic acid, and so it was not possible to specifically assess the flux of glutamine across tissues. Furthermore, since glutamic acid is consistently taken up by peripheral tissues, in contrast to glutamine which is consistently released by peripheral tissues, the combined flux of these two amino acids gives misleading information about the flux of the individual amino acids. Such difficulties do not occur if glutamic acid and glutamine are measured enzymically shortly after sampling.

One of the first observations that highlighted the importance of glutamine in inter-organ flux in man came from forearm and splanchnic catheterization studies in post-absorptive 
and starved subjects (Marliss et al. 1971). Muscle was shown to release substantial quantities of glutamine and the splanchnic tissues took it up. Although the liver has traditionally been assumed to be the organ responsible for the metabolism of amino acids, studies involving simultaneous catheterization of the portal vein, hepatic vein and an artery have shown that the gut is an important tissue that utilizes glutamine in both animals and humans (Felig et al. 1973b; Souba \& Wilmore, 1983; Souba et al. 1985a, b, 1990; Welbourne, 1987; Ardawi et al. 1988). Indeed the gut is probably a more important tissue for the net uptake of glutamine than the liver (Souba et al. 1985 b, 1990a), although there may be species differences, e.g. the sheep liver appears to take up more glutamine than the gut (Heitmann \& Bergman, 1980). Furthermore, perfusion studies of the small intestine showed that glutamine is a major source of energy for this tissue accounting for up to about $35 \%$ of the total $\mathrm{CO}_{2}$ production (Windmueller \& Spaeth, 1974, 1978, 1980; Windmueller, 1982). Glutamine is also considered to be an important energy source for the small intestine in vivo (Windmueller \& Spaeth, 1980; Windmueller, 1982), and it may also be an important fuel for colonocytes (Ardawi \& Newsholme, 1985; Ardawi, 1987). The liver itself has enzymes for synthesizing glutamine (glutamine synthetase) and degrading it (glutaminase), and these are located in different parts of the hepatocytes. The activities of these enzymes which are involved in acid-base regulation (see Haussinger, 1990) may determine whether the liver takes up glutamine or releases it.

Another important organ involved in glutamine metabolism and regulation of acid-base balance is the kidney (Pitts, 1973; Tizianello et al. 1980), which has a high activity of glutamine (EC 3.5.1.2). However, views on the role of renal ammoniagenesis in $\mathrm{pH}$ regulation have changed in recent years. The traditional view is that ammonia is a buffer that is produced by the kidney in order to neutralize acid and, therefore, allow more acid to be excreted in acidotic states (the kidney cannot maintain a urinary $\mathrm{pH}$ below $4 \cdot 0-4.5$ due to the high $\mathrm{pH}$ gradient. The observations that the kidney takes up large quantities of glutamine and has a high activity of glutaminase, which increases further in states of acidosis, is consistent with the traditional view of acid-base regulation, in which glutamine is regarded as an important source of urinary ammonia which is used to buffer urinary acid, especially in states of acidosis, such as starvation or diabetic ketoacidosis. Tracer studies later showed that both $\mathrm{N}$ atoms in glutamine could be used as a source of urinary ammonia. Several workers concluded that about $50 \%$ of the urinary ammonia could be derived from glutamine in normal and acidotic states in animals and humans in vitro and in vivo (Owen \& Robinson, 1963; Pitts et al. 1965; Pitts \& Pilkington, 1966; Stone \& Pitts, 1967; Nissim et al. 1986). Furthermore, during prolonged starvation ammonia replaces urea as the dominant nitrogenous end-product. In such situations up to $50 \%$ of urinary $N$ can be accounted for by ammonia, whereas under normal circumstances only about $5 \%$ of urinary $\mathrm{N}$ excretion is accounted for by ammonia (Owen et al. 1969).

The previously described observations can also be explained by the more recent view that excretion of ammonium ions do not represent excretion of acid. This is because protein oxidation is considered to yield $\mathrm{NH}_{4}^{+}$(from $\mathrm{N}$ groups) and bicarbonate ions (from carboxylate groups) in approximately equimolar amounts without net consumption of hydrogen ions (Atkinson \& Camien, 1982; Atkinson \& Bourke, 1985). According to this view the primary problem is eliminating the $\mathrm{HCO}_{3}^{-}$which will lead to alkalosis. Synthesis of urea in the liver is linked to the regulation of acid-base status since it allows disposal of $\mathrm{HCO}_{3}^{-}$.

$$
2 \mathrm{HCO}_{3}^{-}+2 \mathrm{NH}_{4}^{+} \rightarrow \underset{\text { urea }}{\left(\mathrm{NH}_{2}\right)_{2} \mathrm{CO}}+\mathrm{CO}_{2}+3 \mathrm{H}_{2} \mathrm{O} .
$$

In metabolic acidosis, which occurs during starvation as a result of an increase in circulating ketone-body concentration, the excess protons react with the $\mathrm{HCO}_{3}{ }^{-}$formed 


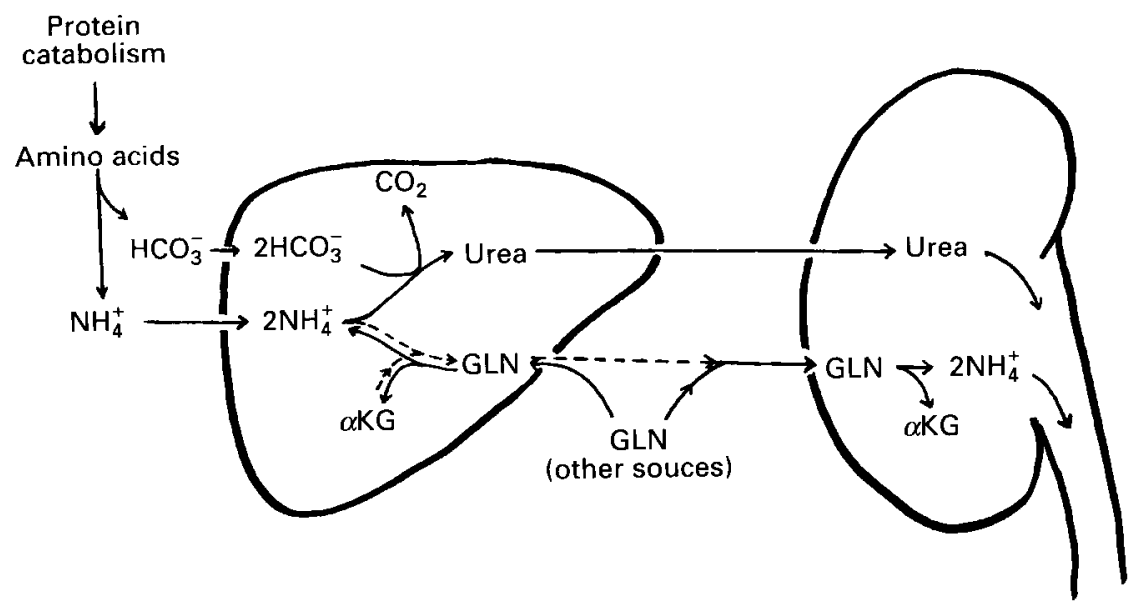

Fig. 5. Co-operation between liver and kidney in acid-base homeostasis. Amino acid oxidation yields ammonium ions and bicarbonate ions which are removed during ureagenesis. In acidosis there is a transfer of $\mathrm{NH}_{4}{ }^{+}$from the liver to the kidney via glutamine $(---\rightarrow)$. $\mathrm{NH}_{4}{ }^{+}$are excreted without $\mathrm{HCO}_{3}{ }^{-}$ (the excess protons in acidosis remove $\mathrm{HCO}_{3}^{-}$by forming carbon dioxide. Glutamine formed in other tissues contributes to renal ammoniagenesis in both normal and acidotic states. However, in alkalosis (or normal acid-base state) the liver takes up glutamine. GLN, glutamine; $\alpha \mathrm{KG}, \alpha$-ketoglutarate.

from protein catabolism, and so there is no need to continue excreting urea. Consequently urea accounts for less than one-quarter of urine $\mathrm{N}$ excretion during prolonged starvation, whilst $\mathrm{NH}_{4}^{+}$excretion, which can be regarded as a means of excreting $\mathrm{N}$ without concomitant $\mathrm{HCO}_{3}^{-}$utilization, becomes the dominant nitrogenous excretory product.

A-V catheterization techniques have shown that the liver may either take up glutamine for net catabolism and urea synthesis (alkalosis/normal acid-base status) or release it as a substrate for renal ammoniagenesis (for review, see Tamarapoo et al. 1990). These observations are consistent with both the traditional and more recent views on acid-base regulation. The co-operative relationships between the liver and kidney are indicated in Fig. 5. The regulatory subtleties and the anatomic borders in the liver that separate the periportal hepatic cells that catabolize the glutamine and generate urea, from the perivenous scavenger cells that synthesize and release glutamine, are discussed in detail elsewhere (Haussinger, 1990).

Another important concept relates to the $\mathrm{C}$ skeleton of glutamine. If large amounts of glutamine or other amino acids are used by the kidney as a source of urinary ammonia during acidosis, e.g. during the mild metabolic acidosis of starvation, the excess $\mathrm{C}$ has to be disposed of. One of the possible fates of this $\mathrm{C}$ is the formation of glucose. Normally the liver is the dominant gluconeogenic organ, but its importance declines during prolonged starvation because the provision of amino acids by peripheral tissues declines. In contrast, renal catheterization studies showed that glucose production by the kidney increased and approximately equalled that produced by the liver (Owen et al. 1969).

The factors that control glutamine utilization by one tissue as opposed to another are important with respect to metabolic regulation. Theoretically a variety of factors could be involved in this regulation including the supply of glutamine from the diet and peripheral tissues, changes in blood flow to specific tissues, and the activity of glutaminases in different tissues. These glutaminases behave differently in various circumstances. For example, renal glutaminase activity increased during acidosis, but this does not necessarily occur for all glutaminases located elsewhere. Furthermore, in the rat a low $\mathrm{HCO}_{3}^{-}$concentration, which 
(a)

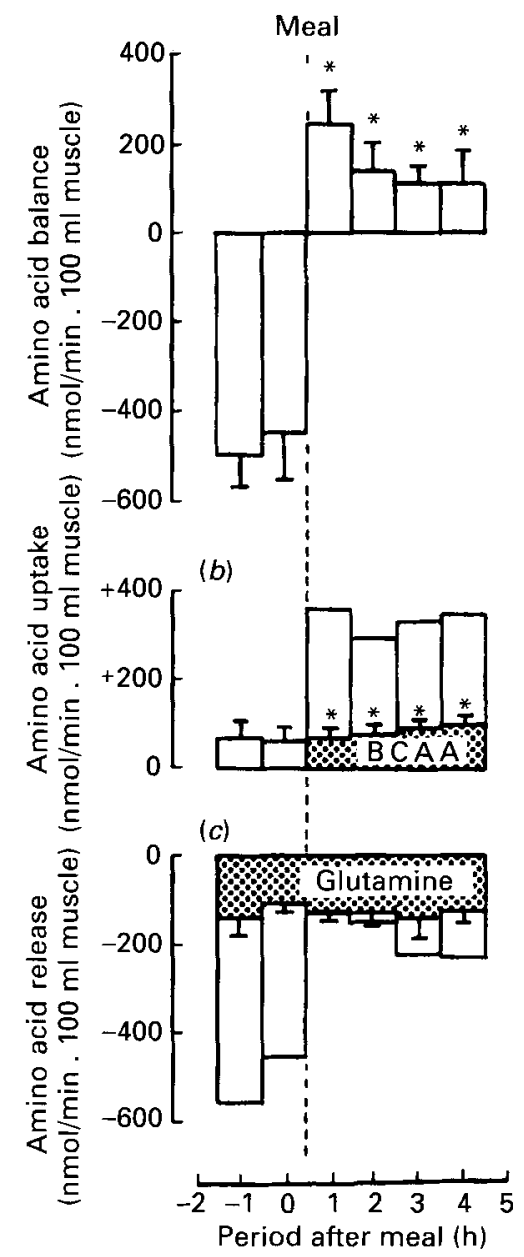

Fig. 6. Effect of a single meal $(3270 \mathrm{~kJ}$, with $47 \cdot 3 \%$ energy from carbohydrate, $39.4 \%$ from fat and $13.2 \%$ from protein) on the exchange of amino acids across forearm muscle. The overall amino acid balance (a) is a combination of increased uptake of amino acids (b) and decreased release (c). (圈), The uptake of branched-chain amino acids (BCAA) and the release of glutamine (GLN). Values are means with their standard errors represented by vertical bars. Mean values were significantly different from basal measurements: ${ }^{*} P<0.01$. From Elia et al. (1989), with permission of the American Journal of Clinical Nutrition.

is a feature of metabolic acidosis, inhibits the hepatic glutaminase but not the renal glutaminase (Baverel \& Lund, 1979). This difference could be one of the factors that could help 'channel' glutamine towards the kidney in states of metabolic acidosis.

It is now recognized that glutamine is potentially an important fuel for a variety of cells (macrophages, fibroblasts and lymphocytes (Brand et al. 1989; Caldwell, 1989; Newsholme \& Newsholme, 1989), and epithelial cells of the intestine) and that its $\mathrm{N}$ is used for the synthesis of nucleic acids. Although a variety of human tissues have been reported to take up glutamine in vivo (intestine, Felig et al. (1973b), liver, Felig et al. (1973b), kidney, Tizianello et al. (1980), and brain, Hagenfeldt et al. (1980)), until a few years ago muscle was considered to be the only major site of glutamine production, and virtually all the 


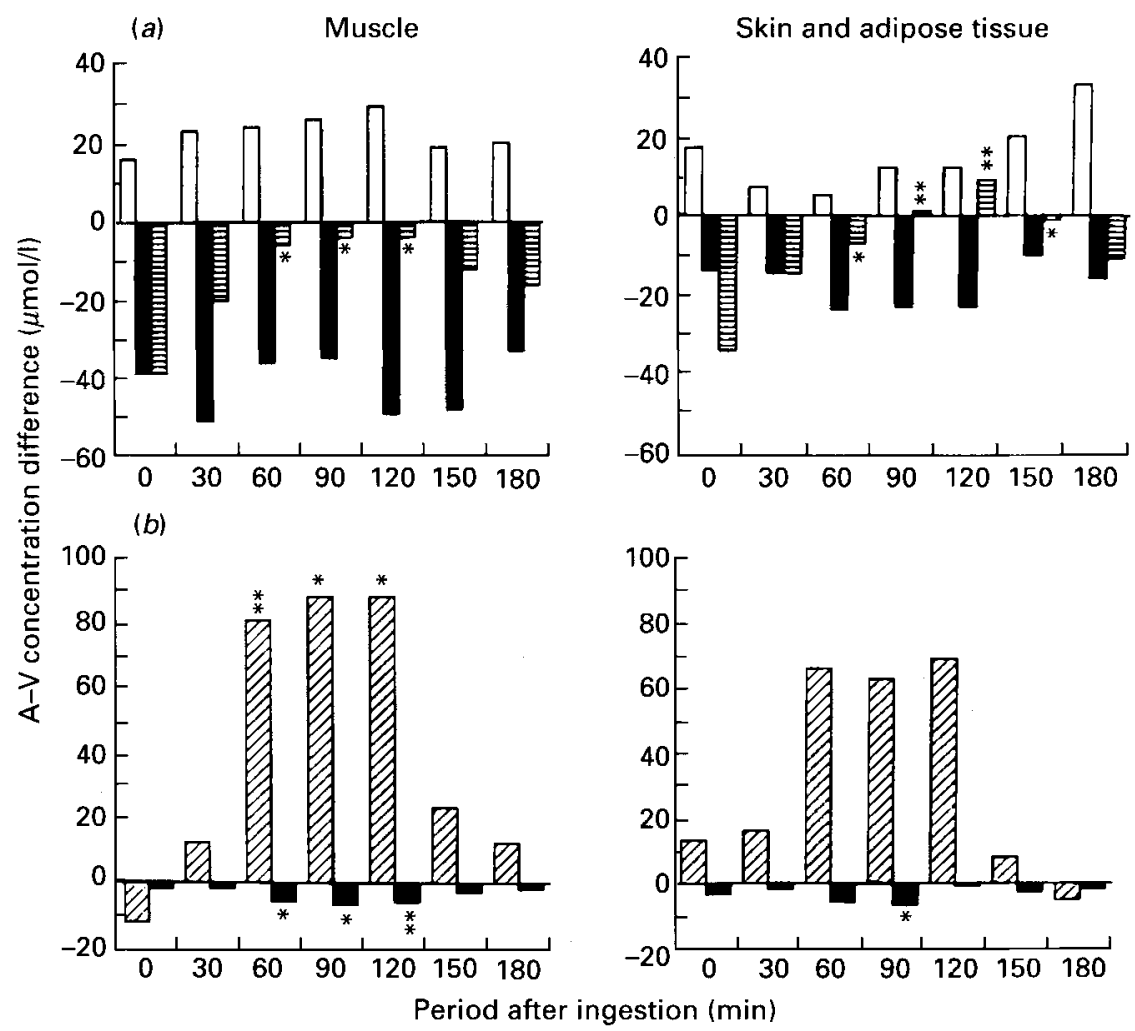

Fig. 7. The effect of ingesting grilled lean beef steak ( $250 \mathrm{~g}$ raw weight) on the arterio-venous (A-V) concentration differences of (a) selected amino acids: glutamate (GLU; $\square$ ), glutamine (GLN; $\square$ ), alanine (ALA; 圈), and branched-chain amino acids (BCAA; 窗), which comprise leucine, isoleucine and valine (b). The release of branched-chain $\alpha$-keto acids (BCOA; $\square$ ) are also indicated. Positive values indicate uptake and negative signs, release $\left({ }^{*} P<0.05,{ }^{*} P<0.01\right)$. The mean arterial concentration of amino acids $(\mu \mathrm{mol} / 1)$ at $0,30,60,90,120,150$, and 180 mins after steak ingestion respectively were as follows: GLU 175, 185, 193, 203, 190 and 194; GLN 588, 590, 617, 646, 630, 639 and 610; ALA 244, $264,321,353,356,363$ and 322 ; BCAA $392,449,636,775,853,794$, and 786 . The corresponding values for BCOA were $54,53,59,60,61,58$, and $54 \mu \mathrm{mol} / 1$. The graphs are primarily intended to show relative rates of exchange of different substrates. Based on Elia (1981), Elia \& Livesey (1981), and Elia \& Livesey (1983).

information about its release was available after an overnight fast. Since then, A-V catheterization studies have provided further information about the inter-organ flux of glutamine and other substrates in the fed state, and have provided evidence of important non-muscular sources of glutamine in both the fed and fasted state.

Elia et al. $(1985,1989)$ undertook a series of studies which showed that glutamine release by the forearm dominated the release of other amino acids after administration of a variety of nutrients: glucose (Elia et al. 1985), BCAA (Elia \& Livesey, 1981, 1983), protein meal (Elia \& Livesey, 1983), mixed meal (Elia et al. 1989), and total parenteral nutrition which lacks glutamine (unpublished results). The rate of release of glutamine after administration of nutrients was generally found to be similar to that which occurred before administration of nutrients, although increased release was noted after administration of leucine. In contrast the release of other amino acids was frequently suppressed. An example of the sequential changes which occur after ingestion of a mixed meal is illustrated in Fig. 6. Whilst most amino acids are taken up after the meal glutamine release continued to occur 


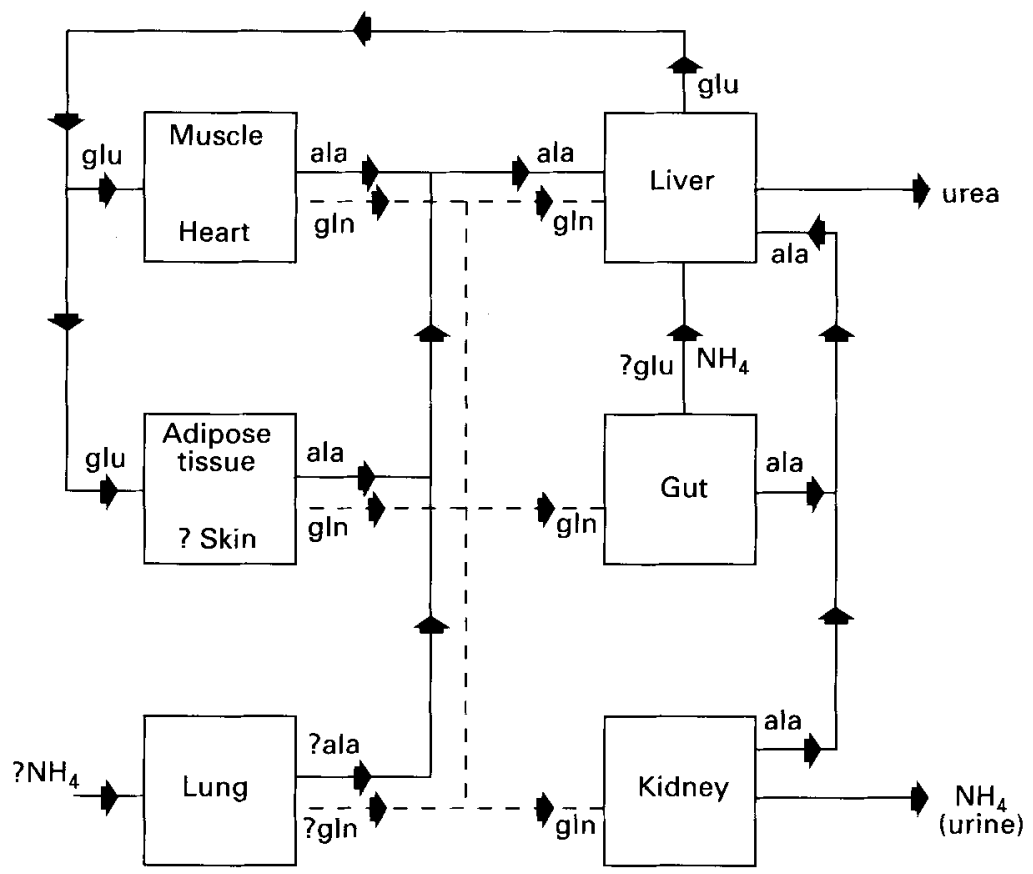

Fig. 8. The flux of glutamate (GLU; $\rightarrow$ ), alanine (ALA; $\rightarrow$ ) and glutamine (GLN; $\longrightarrow-$ ) between various human tissues in the post-absorptive state. The source of urea (liver) and urinary ammonia (kidney) is also indicated.

at a high rate accounting for up to $80 \%$ of the total amino acid released $2 \mathrm{~h}$ after a meal (Fig. 6).

In a more recent collaborative study between the Sheikh Rashid Diabetic Unit in Oxford and our unit in Cambridge, the exchange of amino acids across forearm muscle was measured at the same time as the exchange across subcutaneous abdominal adipose tissue, both before and for $6 \mathrm{~h}$ after ingestion of a mixed meal (Frayn et al. 1991). The study showed that the pattern of amino acids exchange across adipose tissue was similar to that of the forearm, i.e. uptake of glutamate and release of alanine and glutamine. The rates of exchange are considered to be quantitatively important, e.g. the rate of release of glutamine was found to be about $1000 \mathrm{nmol} / \mathrm{kg}$ adipose tissue per min. Therefore, adipose tissue can no longer be regarded as a tissue involved in only fat and carbohydrate metabolism. In further studies, Khan \& Elia (unpublished results), measured A-V concentration differences of metabolites across forearm muscle and across more superficial forearm tissues (skin plus subcutaneous adipose tissue) both before and for $6 \mathrm{~h}$ after ingestion of a mixed meal. The lack of significant $\mathrm{A}-\mathrm{V}$ concentration differences for creatinine suggested that muscle did not contribute to the exchange of metabolites. Furthermore, the A-V concentration differences across muscle, which were measured simultaneously with those across superficial tissues were not large enough to explain the magnitude of the $A-V$ concentration differences across the superficial tissues, even if there was substantial mixing of superficial and deep venous blood. However, the pattern of exchange of amino acids across the superficial tissues was remarkably similar to that of both muscle and adipose tissue (uptake of glutamate and release of alanine and glutamine, both before and after meal ingestion). Since in both this study and the study involving subcutaneous abdominal fat (Frayn et al. 1991), the amount of $\mathrm{N}$ carried out of the tissues in the form of glutamine and alanine was 
greater than that taken up in the form of glutamate, other amino acids must be taken up and metabolized in these tissues, e.g. BCAA, as suggested by in vitro work. Such an uptake has been demonstrated in superficial forearm tissues after ingestion of a protein meal (Fig. 7).

Other studies have suggested that the lung may also be an important site of metabolism of amino acids. The results of $\mathrm{A}$ V catheterization studies across the lung are often difficult to assess accurately because of the large blood flow through the lungs, which results in small $\mathrm{A}-\mathrm{V}$ concentration differences. Small errors in the measurement of glutamine concentration imply large errors in the estimated flux. Nevertheless, there is evidence that glutamine is released by the lungs of animals (Souba et al. 1990 b) and humans (Plumley et al. 1990) in amounts that may exceed that produced normally by the whole musculature of the body muscle (at least in sepsis and possibly post-absorptively in the non-septic state).

Therefore, a complex picture is now emerging (Fig. 8) of the production of alanine and glutamine by a variety of peripheral tissues and the utilization of these amino acids by the liver, gut, kidney, and possibly brain (Hagenfeldt et al. 1980; Felig et al. 1973a). The $\mathrm{N}$ in alanine and glutamine is largely derived from other amino acids, such as glutamic acid and the BCAA, which may also contribute to their $\mathrm{C}$ skeleton (with the exception of leucine, which is a purely ketogenic amino acid; for metabolic pathways, see Garber et al. 1976; Chang \& Goldberg, 1978; Goldstein \& Newsholme, 1976).

\section{BCAA METABOLISM IN PERIPHERAL TISSUES}

The concept that significant amino acid transformations occur in peripheral tissues such as muscle was not always accepted. At one time it was felt that protein synthesis and degradation occurred in muscle without significant amino acid transformation. However, several workers showed muscle preparations could metabolize BCAA (e.g. Manchester, 1965; Goldberg \& Odessey, 1972; Odessey \& Goldberg, 1972). Furthermore, the rate of BCAA metabolism per $\mathrm{g}$ wet tissue was found to be faster in muscle than liver (Meikle \& Klain, 1972; Odessey \& Goldberg, 1972). The enzymes involved in BCAA metabolism were also identified (BCAA aminotransferase $(E C 2.6 .1 .42)$ and branched-chain $\alpha$-keto acid (BCOA) dehydrogenase $(E C$ 1.2.4.4) in humans and in their activities were found to be greater in the musculature of the body than in the liver (Goto et al. 1977; Khatra et al. 1977). It was also found that substantial quantities of dietary BCAA given in the form of a protein meal or a mixed meal escaped initial metabolism in the human liver (estimated to be about half the total quantity of ingested BCAA), and were taken up by muscle, where they accounted for about half the total amino acid uptake by this tissue (Wahren et al. 1976; Elia \& Livesey, 1983; Smith \& Elia, 1983). BCAA were also taken up by muscle after a mixed meal but in this situation they accounted for a smaller proportion of the total amino acid uptake (Fig. 5; Elia et al. 1989). When the uptake of BCAA by muscle is in excess of that required for net protein synthesis, some of it may expand the free amino acid pool in muscle, and the remainder is metabolized.

The development of an enzymic method for measuring BCOA allowed Livesey \& Lund (1980) to undertake A-V catheterization studies across the liver and hind limb of the rat. These studies suggested that BCAA were transaminated in the hind limb, and the resulting BCOA was released into the circulation for subsequent uptake and metabolism in the liver. These observations were consistent with the observations that the activity of BCAA aminotransferase in the musculature of the rat is greater than that in the liver, and that the reverse was true for BCOA dehydrogenase (Shinnick \& Harper, 1976) (cf. man). Later studies (Elia, 1981; Elia \& Livesey, 1983) showed that the release of BCOA by the rat hind 


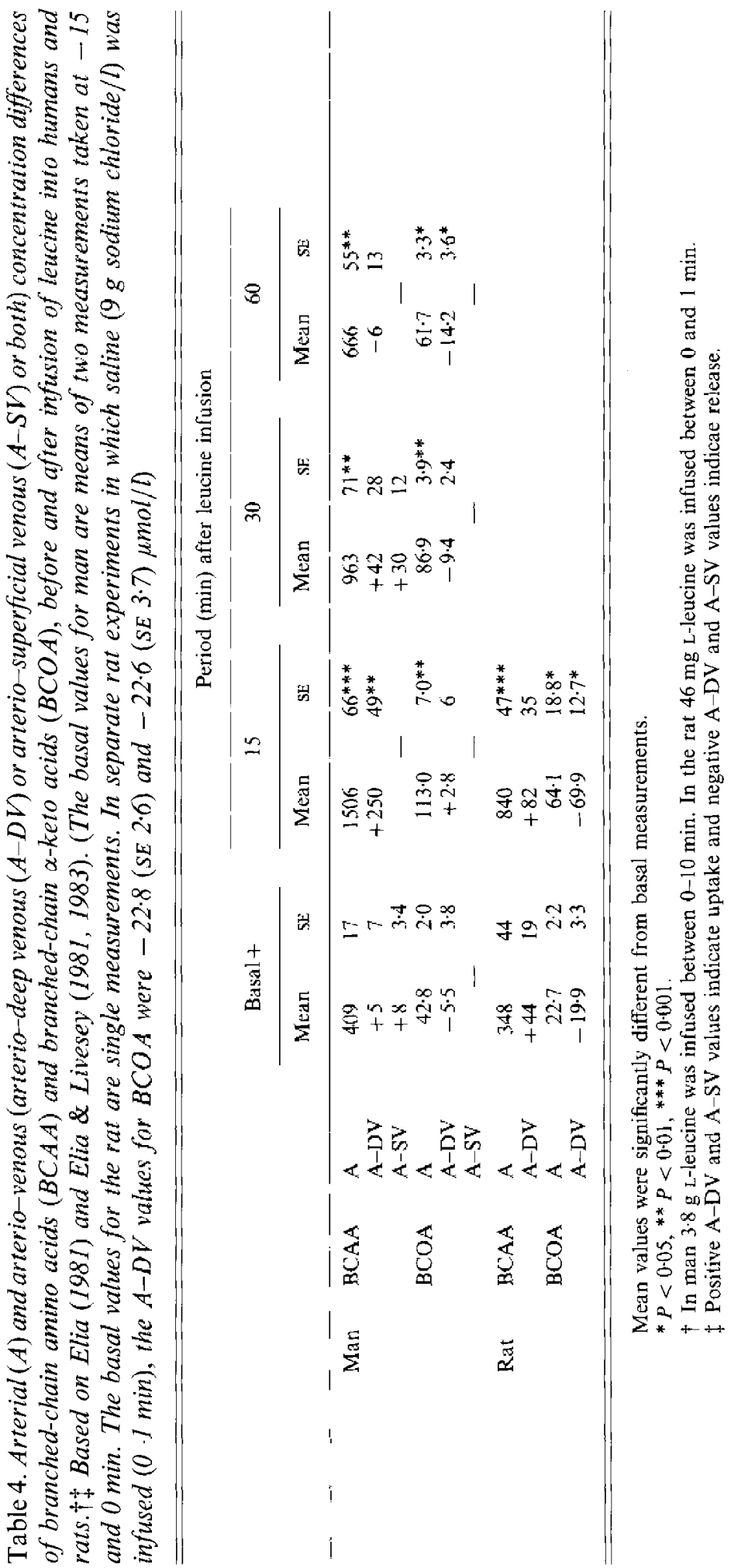


limb could be enhanced considerably by the administration of one of the BCAA (leucine; Table 4).

In man the situation turned out to be different. A-V catheterization studies of the forearm showed that the uptake of substantial quantities of BCAA after administration of leucine (Table 4) or a protein meal (Fig. 4) was associated with relatively little release of BCOA (consistent with the distribution of BCOA dehydrogenase in the human body (Khatra et al. 1977; cf. rat Shinnick \& Harper, 1976). These studies suggest that there is a possible danger in using animal models to study certain human aspects of amino acid metabolism.

\section{CONCLUSION}

The use of regional catheterization techniques in man has shown that there is an intricate and continuous exchange of nutrients between tissues. The way in which substrates are processed during feeding, fasting, physical activity and disease is more complex than previously thought. It is possible for the metabolic function of one tissue to be influenced by the supply of substrates and hormones from a variety of other tissues. The factors that orchestrate this interaction remain an important problem in metabolic regulation. Nevertheless, a further understanding of some of the regulatory processes involved in vivo may be obtained from studies in which the net utilization and flux of nutrients within the body (e.g. assessed by tracer studies, $\mathrm{N}$ excretion, indirect calorimetry) are coupled with measurements of substrate exchange across individual tissues.

\section{REFERENCES}

Abumrad, N. N., Rabin, D., Wise, K. L. \& Lacy, W. W. (1982). The disposal of an intravenously administered amino acid load across the human forearm. Metabolism 31, 463-470.

Addis, T., Poo, L. J. \& Lew, W. (1936). The quantities of protein lost by the various organs and tissues of the body during a fast. Journal of Biological Chemistry 115, 111-116.

Aoki, T. T., Brennan, M. F., Fitzpatrick, G. F. \& Knight, D. C. (1981). Leucine meal increases glutamine and total nitrogen release from forearm muscle. Journal of Clinical Investigation 68, 1522-1528.

Ardawi, M. S. M. (1987). The maximal activity of phosphate-dependent glutaminase and glutamine metabolism in the colon and small intestine of streptozotocin-diabetic rats. Diabetologia 30, 109-114.

Ardawi, M. S. M., Majzoub, M. F. \& Newsholme, E. A. (1988). Effect of glucocorticoid treatment on glucose and glutamine metabolism by the small intestine of the rat. Clinical Science 75, 93-100.

Ardawi, M. S. M. \& Newsholme, E. A. (1985). Fuel utilization in colonocytes of the rat. Biochemical Journal 231, 713-719.

Atkinson, D. E. \& Bourke, E. (1985). The role of ureagenesis in pH homeostasis. In Metabolic regulation, pp. 179-185 [R. S. Ochs, R. W. Hanson and J. Hall, editors]. Amsterdam, New York and Oxford: Elsevier Science Publishers.

Atkinson, D. E. \& Camien, M. N. (1982). The role of urea synthesis in the removal of metabolic bicarbonate and the regulation of blood pH. Current Topics in Cellular Regulation 21, 261-302.

Aulick, J. L. H. \& Wilmore, D. W. (1979). Increased peripheral amino acid release following burn injury. Surgery 85, 560-565.

Balasse, E. O. (1979). Kinetics of ketone body metabolism in fasting humans. Metabolism 28, 41-50.

Balasse, E. O. \& Neef, M. A. (1975). Inhibition of ketogenesis by ketone bodies in fasting humans. Metabolism 24, $999-1007$.

Baverel, G. \& Lund, P. (1979). A role for bicarbonate in the regulation of mammalian glutamine metabolism. Biochemical Journal 184, 599-606.

Bjorkman, O. \& Eriksson, L. S. (1983). Splanchnic glucose metabolism during leg exercise in 60 -hr fasted humans. American Journal of Physiology 245, E443-E448.

Bjorkman, O. \& Eriksson, L. S. (1985). Influence of a $60 \mathrm{hr}$ fast on insulin mediated splanchnic and peripheral glucose metabolism in humans. Journal of Clinical Investigation 76, 87-92.

Bougneres, P.-F. \& Ferre, P. (1987). Study of ketone body kinetics in children by combined perfusion of ${ }^{13} \mathrm{C}$ and ${ }^{2} \mathrm{H}_{3}$ tracers. American Journal of Physiology 253, E496-E501.

Brand, K., Fekl, W., von Hintzenstern, J., Langer, K., Luppa, P. \& Schoerner, C. (1989). Metabolism of glutamine in lymphocytes. Metabolism 38, Suppl. 1, 29-33. 
Brundin, T., Hagenfeldt, L., Soderberg, R. \& Wahren, J. (1987). Blood flow, substrate utilization and heat generation in tissues drained by the azygos vein in man. Clinical Physiology 7, 481-491.

Burrin, D. G., Ferrell, C. L., Eisemann, J. H., Britton, R. A. \& Nienaber, J. A. (1989). Effect of nutrition on splanchnic blood flow and oxygen consumption in sheep. British Journal of Nutrition 62, 23-34.

Cahill, G. F., Herrera, M. G., Morgan, A. P., Soeldner, J. S., Steinke, J., Levy, P. L., Reichard, G. A. \& Kipnis, D. M. (1966). Hormone-fuel interrelationships during fasting. Journal of Clinical Investigation 45, $1751-1769$.

Caldwell, M. D. (1989). Local glutamine metabolism in wounds and inflammation. Metabolism 38, Suppl. 1, 34-39.

Chang, T. W. \& Goldberg, A. L. (1978). The metabolic fates of amino acids and the formation of glutamine in skeletal muscle. Journal of Biological Chemistry 253, 3685-3695.

Coppack, S. W., Fisher, R. M., Gibbons, G. F., Humphreys, S. M., McDonough, M. J., Potts, J. L. \& Frayn, K. N. (1990). Post-prandial substrate deposition in human forearm and adipose tissues in vivo. Clinical Science 79 , 339-348.

da Fonseca-Wollheim, F. (1990). Deamidation of glutamine by increased plasma $\gamma$-glutamyltransferase is a source of rapid ammonia formation in blood and plasma specimens. Clinical Chemistry 36, 1479-1482.

Davies, M. (1961). On body size and tissue respiration. Journal of Cellular and Comparative Physiology 57, 135-147.

Dietze, G. J. (1983). Inter-organ substrate flow. In New Aspects of Clinical Nutrition, pp. 146-168 [G. Kleinberger and E. Deuch, editors]. Basel: Karger.

Dietze, G., Wicklmayr, M. \& Mehnert, H. (1978). On the key role of ketogenesis for the regulation of glucose homeostasis during fasting: intrahepatic control, ketone levels and peripheral pyruvate oxidation. In Biochemical and Clinical Aspects of Ketone Body Metabolism, pp. 213-225 [H. D. Soling and C. D. Seufert, editors]. Stuttgart: Thieme.

Dietze, G., Wicklmayr, M., Schifman, R. \& Mehnert, H. (1980). Metabolic fuels in fasting. Excerpta Medica International Congress Series 500, 314-320.

Elia, M. (1981). Metabolic aspects of injury, starvation and other conditions in man. MD Thesis, Manchester University.

Elia, M. (1991 a). The energy equivalents of carbon dioxide (EeqCo2) and their importance in assessing energy expenditure when using tracer techniques. American Journal of Physiology 260, E75-E88.

Elia, M. (1991 b). Energy expenditure in the whole body and individual human tissues, and the energy cost associated with specific metabolic processes. In Energy Metabolism: Tissue Determinants and Cellular Corollaries [J. M. Kinney, editor]. Raven Press.

Elia, M., Crozier, C. \& Neale, G. (1984a). Mineral metabolism during short-term starvation in man. Clinica Chimica Acta 139, 37-45.

Elia, M., Folmer P., Schlatmann, A., Goren, A. \& Austin, S. (1988). Carbohydrate fat and protein metabolism in muscle and in the whole body after mixed meal ingestion. Metabolism 37, 542-551.

Elia, M., Folmer, P., Schlatmann, A., Goren, A. \& Austin, S. (1989). Amino acid metabolism in muscle and in the whole body of man before and after ingestion of a single mixed meal. American Journal of Clinical Nutrition 49, 1203-1210.

Elia, M., Ilic, V., Bacon, S., Williamson, D. H. \& Smith, R. (1980). Relationship between the basal blood alanine concentration and removal of an alanine load in various clinical states in man. Clinical Science $\mathbf{5 8}$, 301-309.

Elia, M. \& Jebb, S. A. (1990 a). Assessment of energy expenditure and body composition. Medicine International 82, 3407-3410.

Elia, M. \& Jebb, S. A. $(1990 \mathrm{~b})$. Assessment of body composition : research techniques and bedside methods. South African Journal of Clinical Nutrition 3, 21-26.

Elia, M., Lammert, O., Zed, C. \& Neale, G. (1984b). Energy metabolism during exercise in normal subjects undergoing total starvation. Human Nutrition: Clinical Nutrition 38C, 355-362.

Elia, M. \& Livesey, G. (1981). Branched-chain amino acid and oxo acid metabolism in human and rat muscle. In Metabolism and Clinical Implications of Branched Chain Amino and Keto Acids, pp. 257-262 [M. Walser and J. R. Williamson, editors]. New York, Amsterdam, Oxford: Elsevier/North Holland.

Elia, M. \& Livesey, G. (1983). Effects of ingested steak and infused leucine on forelimb metabolism in man and the fate of the carbon skeletons and amino groups of branched-chain amino acids. Clinical Science 64, 517-526.

Elia, M. \& Livesey, G. (1988). The theory and validity of indirect calorimetry during net lipid synthesis (Appendix). American Journal of Clinical Nutrition 47, 591-607.

Elia, M., Neale, G. \& Livesey, G. (1985). Alanine and glutamine release from the human forearm: effects of glucose administration. Clinical Science 69, 123-133.

Elia, M. \& Parkinson, S. (1989). Protein economy during human starvation. European Journal of Clinical Nutrition 43, 139-143.

Elia, M., Wood, S., Khan, K. \& Pullicino, E. (1990). Ketone body metabolism in lean male adults during shortterm starvation, with particular reference to forearm muscle metabolism. Clinical Science 78, 579-584

Elia, M., Zed, C., Neale, G. \& Livesey, G. (1987). The energy cost of triglyceride-fatty acid recycling in non-obese subjects after an overnight fast and four days of starvation. Metabolism 36, 251-255.

Elwyn, D. H., Launder, W. J., Parikh, H. C. \& Wise, E. M. (1972). Roles of plasma and erythrocytes in interorgan transport of amino acids in dogs. American Journal of Physiology 222, 1333-1342. 
Eriksson, L. S., Olsson, M. \& Bjorkman, O. (1988). Splanchnic metabolism of amino acids in healthy subjects Effects of $60 \mathrm{hrs}$ of fasting. Metabolism 37, 1159-1162.

Felig, P. (1973). The glucose alanine cycle. Metabolism 22, 179-207.

Felig, P., Marliss, E. B. \& Cahill, G. F. (1971). Metabolic response to human growth hormone during prolonged starvation. Journal of Clinical Investigation 50, 411-421.

Felig, P., Owen, O. E., Wahren, J. \& Cahill, G. F. (1969). Amino acid metabolism during prolonged starvation. Journal of Clinical Investigation 48, 584-594.

Felig, P., Pozefsky, T., Marliss, E. \& Cahill, G. F. (1970). Alanine, key role in gluconeogenesis. Science 167, $1003-1004$

Felig, P. \& Wahren, J. (1971). Amino acid metabolism in exercising man. Journal of Clinical Investigation 50, $2703-2714$

Felig, P. \& Wahren, J. (1975). Liver as a site of insulin and glucagon action in normal, diabetic and obese humans. Israel Journal of Medical Sciences 11, 528-539.

Felig, P., Wahren, J. \& Ahlborg, G. (1973a). Uptake of individual amino acids by the human brain. Proceedings of the Society for Experimental Biology and Medicine 142, 230-231.

Felig, P., Wahren, J. \& Hendler, R. (1975). Influence of oral glucose ingestion on splanchnic glucose and gluconeogenic substrate metabolism in man. Diabetes $\mathbf{2 4}, 468-475$.

Felig, P., Wahren, J. \& Raf, L. (1973 b). Evidence of inter-organ amino acid transport by blood cells in humans. Proceedings of the National Academy of Sciences of the USA 70, 1775-1779.

Ferrannini, E., Wahren, J., Felig, P. \& De Fronzo, R. A. (1980). The role of fractional glucose extraction in the regulation of splanchnic glucose metabolism in normal and diabetic man. Metabolism 29, 28-35.

Fery, F. \& Balasse, E. O. (1983). Ketone body turnover during and after exercise in overnight fasted and starved humans. American Journal of Physiology 245, E318-E325.

Fery, F. \& Balasse, E. O. (1986). Response of ketone body metabolism to exercise during transition from the postabsorptive to fasted state. American Journal of Physiology 250, E495-E501.

Foster, K. J., Alberti, K. G. M. M., Binder, C., Hinks, L., Karran, S. J., Orskov, H., Smythe, P., Talbot, S. \& Turnell, D. (1979). Lipid metabolites and nitrogen balance after abdominal surgery in man. British Journal of Surgery 66, 242-245.

Frayn, K. N., Khan, K., Coppack, S. W. \& Elia, M. (1991). Amino acid metabolism in human subcutaneous adipose tissue in vivo. Clinical Science 80, 471-474.

Fulks, R. M., Li, J. B. \& Goldberg, A. L. (1975). Effect of insulin, glucose, and amino acids on protein turnover in rat diaphragm. Journal of Biological Chemistry 250, 290-298.

Garber, A. J., Karl, I. E. \& Kipnis, D. M. (1976). Alanine and glutamine synthesis and release from skeletal muscle. II. The precursor role of amino acids in alanine and glutamine synthesis. Journal of Biological Chemistry 251, 836-843.

Garber, A. J., Menzel, P. H., Boden, G. \& Owen, O. E. (1974). Hepatic ketogenesis and gluconeogenesis in humans. Journal of Clinical Investigation 54, 981-989.

Garby, L., Garrow, J. S., Jorgensen, B., Lammert, O., Madsen, K., Sorensen, P. \& Webster, J. (1987). Relation between energy expenditure and body composition in man: specific energy expenditure in vivo of fat and fat free tissue. European Journal of Clinical Investigation 42, 301-305.

Gelfand, R. A., Glickman, M. G., Jacob, R., Sherwin, R. S. \& De Fronzo, R. A. (1986). Removal of infused amino acids by splanchnic and leg tissues in humans. American Journal of Physiology 250, E407-E413.

Goldberg, A. L. \& Odessey, R. (1972). Oxidation of amino acids by diaphragms from fed and fasted rats. American Journal of Physiology 223, $1384-1391$.

Goldstein, L. \& Newsholme, E. A. (1976). The formation of alanine from amino acids in diaphragm muscle of the rat. Biochemistry 154, 554-558.

Goschke, H. (1977). Mechanism of glucose intolerance during fasting: differences between lean and obese subjects. Metabolism 26, 1147-1153.

Goschke, H., Girard, J. \& Stahl, M. (1976). Der stoffwechsell bei vollstandigem Fasten. Unterschiedliches Verhalten bei Mannern und Frauen sowie bei Normalpersonen und Adiposen. (Metabolic differences between males and females and between normal and obese subjects during a total fast.) Klinische Wochenschrift 54, $527-553$.

Goschke, H., Nisoli, M., Leutenegger, A. \& Tholen, H. (1977). Comparison of glucose and fructose tolerance before and after starvation. American Journal of Clinical Nutrition 30, 1398-1401.

Goschke, H., Stahl, M. \& Tholen, H. (1975). Nitrogen loss in normal and obese subjects during total fast. Klinische Wochenschrift 53, 605-610.

Goto, M., Shinno, H. \& Ichihara, A. (1977). Isozyme patterns of branched-chain amino acid transaminase in human tissues and tumours. Gann 68, 663-667.

Hagenfeldt, L., Eriksson, S. \& Wahren, J. (1980). Influence of leucine on the arterial concentrations and regional exchange of amino acids in healthy subjects. Clinical Science 59, 173-181.

Hagenfeldt, L. \& Wahren, J. (1971). Human forearm muscle metabolism during exercise VI. Substrate utilization in prolonged fasting. Scandinavian Journal of Clinical and Laboratory Investigation 27, 299-306.

Hall, S. E. H., Wastney, M. E., Bolton, T. M., Braaten, J. T. \& Berman, M. (1984). Ketone body kinetics in humans: The effects of insulin dependent diabetes, obesity and starvation. Journal of Lipid Research $\mathbf{2 5}$, $1184-1194$. 
Hallgren, P., Sjostrom, L., Hedlund, H., Lundell, L. \& Olbe, L. (1989). Influence of age, fat cell weight, and obesity on oxygen consumption of human adipose tissue. American Journal of Physiology 256, E467-E474.

Haussinger, D. (1990). Nitrogen metabolism in liver: structural and functional organization and physiological relevance. Biochemical Journal 267, 281-290.

Haymond, M. W., Karl, I. E., Clarke, W. L., Pagliara, A. S. \& Santiago, J. V. (1982). Differences in circulating gluconeogenic substrates during short term fasting in men, women and children. Metabolism 31, 33-42.

Heitmann, R. N. \& Bergman, E. N. (1980). Integration of amino acid metabolism in sheep: effects of fasting and acidosis. American Journal of Physiology 239, E248-E254.

Henry, C. J. K., Rivers, J. P. W. \& Payne, P. R. (1986). Does the pattern of tissue mobilization dictate protein requirements. Human Nutrition: Clinical Nutrition 40C, 87-92.

Heymsfield, S. B. \& McManus, C. B. (1985). Tissue components of weight loss in cancer patients. A new method of study and preliminary observations. Cancer 55, 238-249.

Jackson, R. A., Hamling, J. B., Sim, B. M., Hawa, M. I., Blix, P. M. \& Nabarro, J. D. N. (1987). Peripheral lactate and $\mathrm{O}_{2}$ metabolism in man: The influence of oral glucose loading. Metabolism 36, 144-150.

Jensen, D. M., Haymond, M. W., Gerich, J. E., Cryer, P. E. \& Miles, J. M. (1987). Lipolysis during fasting. Decreased suppression by insulin and increased stimulation by epinephrine. Journal of Clinical Investigation 79 , $207-213$.

Khan, K. \& Elia, M. (1991). Factors affecting the stability of glutamine in solution. Clinical Nutrition, 10, $186-192$.

Khatra, B. S., Chawla, R. K., Sewell, C. W. \& Rudman, D. (1977). Distribution of branched-chain $\alpha$-keto acid dehydrogenases in primate tissues. Journal of Clinical Investigation 59, 558-564.

Kominz, D. R., Hough, A., Symonds, P. \& Laki, K. (1954). The amino acid composition of actin, myosin, tropomyosin and meromyosins. Archives of Biochemistry and Biophysics 50, 148-159.

Livesey, G. \& Elia, M. (1988). The estimation of energy expenditure, net carbohydrate utilization, and net fat oxidation and synthesis by indirect calorimetry: evaluation of errors with special reference to the detailed composition of fuels. American Journal of Clinical Nutrition 47, 608-628.

Livesey, G. \& Lund, P. (1980). Enzymatic determination of branched-chain amino acids and 2-oxoacids in rat tissues. Transfer of 2-oxoacids from skeletal muscle to liver in vivo. Biochemical Journal 188, 705-713.

Lonsdale, D., Faulkner, W. R., Price, J. W. \& Smeby, R. R. (1969). Intermittent cerebellar ataxia associated with hyperpyruvic acidaemia and hyperalaninaemia. Pediatrics 43, 1025-1033.

Mallette, L. E., Exton, J. H. \& Park, C. R. (1969). Control of gluconeogenesis from amino acids in the perfused rat liver. Journal of Biological Chemistry 244, 5713-5723.

Manchester, K. L. (1965). Oxidation of amino acids by isolated rat diaphragm and the influence of insulin. Biochimica et Biophysica Acla 100, 295-298.

Marliss, E. B., Aoki, T. T., Pozefsky, T., Most, A. S. \& Cahill, G. F. (1971). Muscle and splanchnic glutamine and glutamate metabolism in postabsorptive and starved man. Journal of Clinical Investigation 50, 814-817.

Meikle, A. W. \& Klain, G. J. (1972). Effect of fasting and fasting refeeding on conversion of leucine to $\mathrm{CO}_{2}$ and lipids in rats. American Journal of Physiology 222, 1246-1250.

Merimee, T. J., Misbin, R. I. \& Pulkkinen, A. J. (1978). Sex variations in free fatty acids and ketones during fasting. Evidence for a role of glucagon. Journal of Clinical Endocrinology \& Metabolism 46, 414-419.

Morrow, P. G., Marshall, W. P., Kim, H. J. \& Kalkhoff, R. K. (1981). Metabolic response to starvation II. Effects of sex steroid administration to pre- and postmenopausal women. Metabolism 30, 274-278.

Newsholme, P. \& Newsholme, E. A. (1989). Rates of utilization of glucose, glutamine and oleate and formation of end-products by mouse peritoneal macrophages in culture. Biochemical Journal 261, 211-218.

Nissim, I., Yudkoff, M. \& Segal, S. (1986). Nitrogen sources for renal ammoniagenesis: study with ${ }^{15} \mathrm{~N}$ amino acid. American Journal of Physiology 251, F995-F1002.

Odessey, R. \& Goldberg, A. L. (1972). Oxidation of leucine by rat skeletal muscle. American Journal of Physiology 223, 1376-1383.

Odessey, R., Khairallah, E. A. \& Goldberg, A. L. (1974). Origin and possible significance of alanine production by skeletal muscle. Journal of Biological Chemistry 249, 7623-7629.

Owen, O. E., Felig, P., Morgan, A. P., Wahren, J. \& Cahill, G. F. (1969). Liver and kidney metabolism during prolonged starvation. Journal of Clinical Investigation 48, 574-583.

Owen, O. E., Morgan, A. P., Kemp, H. G., Sullivan, J. M., Herrera, M. G. \& Cahill, G. F. (1967). Brain metabolism during fasting. Journal of Clinical Investigation 46, 1589-1595.

Owen, O. E. \& Reichard, G. A. (1971). Human forearm metabolism during progressive starvation. Journal of Clinical Investigation 50, $1536-1545$.

Owen, O. E. \& Reichard, G. A. (1975). Ketone body metabolism in normal, obese and diabetic subjects. Israel Journal of Medical Sciences 11, 560-570.

Owen, O. E., Reichard, G. A., Markus, H., Boden, G., Mozzoli, M. A. \& Shuman, C. R. (1973). Rapid intravenous sodium acetoacetate infusion in man: metabolic and kinetic responses. Journal of Clinical Investigation 52, $2606-2616$.

Owen, O. E., Reichle, F. A., Mozzoli, M. A., Kreulen, T., Patel, M. S., Elfenbein, I. B., Golsorkhi, M., Chang, K. H. Y., Rao, N. S., Sue, H. S. \& Boden, G. (1981). Hepatic, gut and renal substrate flux rates in patients with hepatic cirrhosis. Journal of Clinical Investigation 68, 240-252.

Owen, O. E. \& Robinson, R. R. (1963). Amino acid extraction and ammonia metabolism by the human kidney during prolonged administration of ammonium chloride. Journal of Clinical Investigation 42, $263-276$. 
Pitts, R. F. (1973). Production and excretion of ammonia in relation to acid base regulation. Handbook of Physiology, sect. 8, pp. 455 496. Washington, DC: American Physiological Society.

Pitts, R. F. \& Pilkington, L. A. (1966). The relation between plasma concentrations of glutamine and glycine and utilization of their nitrogens as sources of urinary ammonia. Journal of Clinical Investigation 45, 86-93.

Pitts, R. F., Pilkington, L. A. \& De Haas, J. M. C. (1965). ${ }^{15} \mathrm{~N}$ tracer studies on the origin of urinary ammonia in the acidotic dog with notes on the enzymatic synthesis of labelled glutamic acid and glutamine. Journal of Clinical Investigation 44, 731-745.

Plumley, D. A., Souba, W. W., Hautamaki, R. D., Martin, T. D., Flynn, T. C., Rout, W. R. \& Copeland, E. M. (1990). Accelerated lung amino acid release in hyperdynamic septic surgical patients. Archives of Surgery 125 , 57-61.

Pozefsky, T., Felig, P., Tobin, J. D., Soeldner, S. \& Cahill, G. F. (1969). Amino acid balance across tissues of the forearm in post-absorptive man. Effect of insulin at two dose levels. Journal of Clinical Investigation 48 2273-2282.

Pozefsky, T. \& Tancredi, R. G. (1972). Effects of intrabrachial arterial infusion of pyruvate on forearm tissue metabolism: interrelationships between pyruvate lactate and alanine. Journal of Clinical Investigation 51, 2359-2369.

Pullicino, E. \& Elia, M. (1991). Intravenous carbohydrate overfeeding: a method for rapid nutritional repletion. Clinical Nutrition 10, 146-154.

Randle, P. J. (1978). Pyruvate dehydrogenase complex - meticulous regulator of glucose disposal in animals. Trends in Biochemical Sciences 3, 217-219.

Reichard, G. A., Haff, A. C., Skutches, C. L., Paul, P., Holroyde, C. P. \& Owen, O. E. (1979). Plasma acetone metabolism in fasting humans. Journal of Clinical Investigation 63, 619-626.

Reichard, G. A., Owen, O. E., Haff, A. C., Paul, P. \& Bortz, W. M. (1974). Ketone body production and oxidation in fasting obese humans. Journal of Clinical Investigation 53, 508-513.

Rennie, M. J., Hundal, H. S., Babij, P., MacLennan, P., Taylor, P. M., Watt, P. W., Jepson, M. M. \& Millward, D. J. (1986). Characteristics of a glutamine carrier in skeletal muscle have important consequences for nitrogen loss in injury, infection and chronic disease. Lancet ii, 1008-1012.

Robinson, A. M. \& Williamson, D. H. (1980). Physiological roles of ketone bodies as substrates and signals in mammalian tissues. Physiological Reviews 60, 143-187.

Sapir, D. G. \& Owen, O. E. (1975). Renal conservation of ketone bodies during starvation. Metabolism 24, 23-33.

Shinnick, F. L. \& Harper, A. E. (1976). Branched-chain amino acid oxidation by isolated rat tissue preparations. Biochimica et Biophysica Acta 437, 477-486.

Smith, R. \& Elia, M. (1983). Branched-chain amino acids in catabolic states. Proceedings of the Nutrition Society 42, 473-487.

Snell, K. \& Duff, D. A. (1977). The release of alanine by rat diaphragm muscle in vitro. Biochemical Journal 162 , 399- 403.

Snyder, W. S., Cook, M. J., Nasset, E. S., Karhausen, L. R., Howells, G. P. \& Tipton, I. H. (1975). Report of the Task Group on Reference Man. International Commission on Radiological Protection no. 23. Oxford, New York, Toronto, Sydney and Braunschweig: Pergamon Press.

Souba, W. W., Herskowitz, K., Klimberg, V. S., Salloum, R. M., Plumley, D. A., Flynn, T. C. \& Copeland, E. M. (1990a). The effects of sepsis and endotoxaemia on gut glutamine metabolism. Annals of Surgery 211, $543-551$.

Souba, W. W., Plumley, D. A., Salloum, R. M. \& Copeland, E. M. (1990 b). Effect of glucocorticoids on lung glutamine and alanine metabolism. Surgery 108, 213-219.

Souba, W. W., Scott, T. E. \& Wilmore, D. W. (1985a). Intestinal consumption of intravenously administered fuels. Journal of Parenteral and Enteral Nutrition 9, 18-22.

Souba, W. W., Smith, R. J. \& Wilmore, D. W. (1985 b). Effects of glucocorticoids on glutamine metabolism in visceral organs. Metabolism 34, 450456.

Souba, W. W. \& Wilmore, D. W. (1983). Postoperative alteration of arterio-venous exchange of amino acids across the gastrointestinal tract. Surgery 94, 342-349.

Stone, W. J. \& Pitts, R. F. (1967). Pathways of ammonia metabolism in the intact functioning kidney of the dog. Journal of Clinical Investigation 46, 1141-1150.

Swaminathan, R., Morgan, D. B. \& Wales, J. K. (1982). Effect of fasting on the disappearance of injected alanine and 3-hydroxybutyrate in obese subjects. Clinical Science 62, 77-81.

Tamarappoo, B. K., Joshi, S. \& Welbourne, T. C. (1990). Interorgan glutamine flow regulation in metabolic acidosis. Mineral and Electrolyte Metabolism 16, 322-330.

Tizianello, A., De Ferrari, G., Garibotto, G., Gurreri, G. \& Robands, C. (1980). Renal metabolism of amino acids and ammonia in subjects with normal renal function and in patients with chronic renal insufficiency. Journal of Clinical Investigation $\mathbf{6 5}, 1162-1173$.

Wahren, J., Felig, P. \& Hagenfeldt, L. (1976). Effect of protein ingestion on the splanchnic and leg metabolism in normal man and in patients with diabetes mellitus. Journal of Clinical Investigation 57, 987-999.

Wahren, J., Felig, P., Havel, R. J., Jorfeldt, L., Pernow, B. \& Saltin, B. (1973). Amino acid metabolism in McArdles Syndrome. New England Journal of Medicine 288, 774-777.

Weast, R. C. (1976). Handbook of Chemistry and Physics (57th edn), pp. D274-D279. Boca Raton, FL: CRC. 
Welbourne, T. C. (1987). Interorgan glutamine flow in metabolic acidosis. American Journal of Physiology 253, F1069 F1076.

Williamson, D. H. \& Whitelaw, E. (1978). Physiological aspects of the regulation of ketogenesis. Biochemical Society Symposium 43, 137-161.

Wilmore, D. W. \& Aulick, L. H. (1978). Metabolic changes in burned patients. Surgical Clinics of North America 58, 1173-1187.

Wilmore, D. W., Goodwin, C. W., Aulick, L. H., Powanda, M. C., Mason, A. D. \& Pruit, B. A. (1980). Effect of injury and infection on visceral metabolism and circulation. Annals of Surgery 192, 491-504.

Windmueller, H. G. (1982). Glutamine utilization by the small intestine. Advances in Enzymology 53, $201-237$.

Windmueller, H. G. \& Spaeth, A. E. (1974). Uptake and metabolism of plasma glutamine by the small intestine. Journal of Biological Chemistry 249, 5070-5079.

Windmueller, H. G. \& Spaeth, A. E. (1978). Identification of ketone bodies and glutamine as the major respiratory fuels in vivo for postabsorptive rat small intestine. Journal of Biological Chemistry 253, 69-76.

Windmueller, H. G. \& Spaeth, A. E. (1980). Respiratory fuel and nitrogen metabolism in vivo in small intestine of fed rats. Journal of Biological Chemistry 255, $107-112$.

Wise, J. K., Hendler, R. \& Felig, P. (1973). Influence of glucocorticoids on glucagon secretion and plasma amino acid concentration in man. Journal of Clinical Investigation 52, 2774-2782.

Wolfe, B. M., Havel, J. R., Marliss, E. B., Kane, J. P., Seymour, J. \& Ahuja, S. P. (1976). Effect of a 3-day fast and of ethanol on splanchnic metabolism of free fatty acids, amino acids, and carbohydrates in healthy young men. Journal of Clinical Investigation 57, 329-340.

Wusteman, M., Wight, D. G. D. \& Elia, M. (1990). Protein metabolism after 'injury' with turpentine: a rat model for clinical trauma. American Journal of Physiology 259, E763-E769.

Zurlo, F., Larson, K., Bogardus, C. \& Ravussin, E. (1990). Skeletal muscle metabolism is a major determinant of resting energy expenditure. Journal of Clinical Investigation 86, 1423-1427. 